Life Sciences Contributions 78
Royal Ontario Museum

\title{
Form, Structure and Function of Shell and Siphuncle in Coiled Mesozoic Ammonoids
}

G. E. G. Westermann

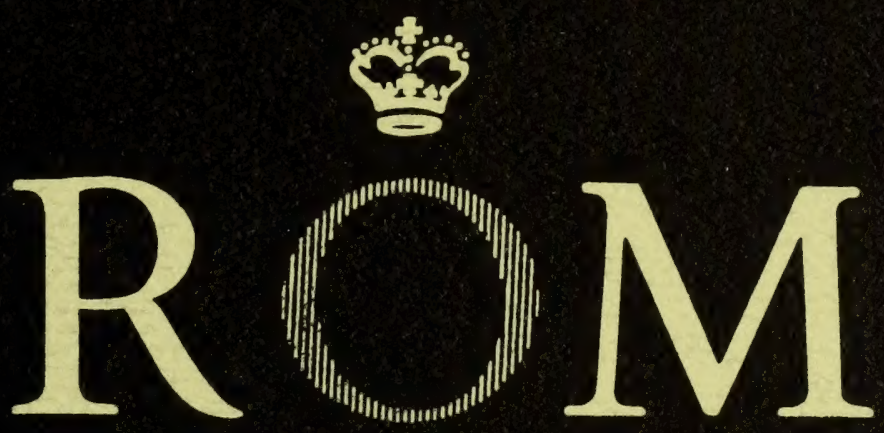


Digitized by the Internet Archive in 2011 with funding from University of Toronto 
LIFE SCIENCES CONTRIBUTIONS

ROYAL ONTARIO MUSEUM

NUMBER 78

\section{Form, Structure and Function}

G. E. G. WESTERMANN

\section{of Shell and Siphuncle in \\ Coiled Mesozoic Ammonoids}

Publication date: 15 March 1971

Suggested citation: Life Sci. Contr., R. Ont. Mus. 


\section{ROYAL ONTARIO MUSEUM \\ PUBLICATIONS IN LIFE SCIENCES}

The Royal Ontario Museum publishes three series in the Life Sciences:

LIFE SCIENCES CONTRIBUTIONS, a numbered series of original scientific publications, including monographic works.

LIFE SCIENCES OCCASIONAL PAPERS, a numbered series of original scientific publications, primarily short and usually of taxonomic significance.

LIFE SCIENCES MISCELLANEOUS PUBLICATIONS, an unnumbered series of publications of varied subject matter and format.

All manuscripts considered for publication are subject to the scrutiny and editorial policies of the Life Sciences Editorial Board, and to review by persons outside the Museum staff who are authorities in the particular field involved.

LIFE SCIENCES EDITORIAL BOARD, 1969-1970

Chairman: P. C. SWANN

Director, Royal Ontario Museum

Editors: R. L. PETERSON

E. J. CROSSMAN

G. E. G. WESTERMANN, Department of Geology, McMaster University, Hamilton, Ontario, is a Research Associate in the Department of Invertebrate Palaeontology, Royal Ontario Museum.

PRICE: $\$ 2.00$

(C)The Royal Ontario Museum, 1971

100 Queen's Park, Toronto, Canada

PRINTED AT MCCORQUODALE \& BLADES PRINTERS LIMITED 


\section{Contents}

Abstract, 1
A. Introduction, 2
B. Material, 3
C. Shell Form, 4

1. Whorl Section and Coiling, 4

2. Ornament, 7

3. Keel, 8

4. Interrelation between Shape and Ornament, 8

5. Aperture, 9

D. Structure of the Shell Wall, 11

1. Wall Thickness, 12

E. Septum and Suture, 15

1. Septal Thickness, 15

2. Shape, 18

3. Septal Lobe, 22

F. Siphuncle, 22

G. Growth Rate and Span, 29

H. Growth of the Body Chamber, Orientation and Buoyancy Control, 30

I. Bathymetry and Siphuncular Strength, 33

Literature Cited, 36 



\title{
Form, Structure and Function of Shell and Siphuncle in Coiled Mesozoic Ammonoids
}

\begin{abstract}
A review of recent literature, an examination of Jurassic and Cretaceous ammonoids, and comparison with fossil and present day nautiloids have produced partly confirmative and partly new interpretations of shell structure, functions and their relationship to cephalopod habitats. Coiling and crosssection of the shell are complexly related to stability, hydrostatic pressure, test economy, buoyancy, compactness, and streamlining and are interdependent with ornament. The whorl cross-section commonly follows a simple or modified catenary curve serving to increase stability. The adult body chamber of Ammonitina decreases in volume relative to the phragmocone, but gains in buoyancy are probably compensated for by wall thickening and apertural modification; enlarged coiling and rounding of section increase shell stability. The phragmocone wall of Ammonitina and Lytoceratina tends to be thinner than in Phylloceratidae and Nautilidae; the dorsal wall is present in Lytoceratina and is rare in Ammonitina.
\end{abstract}

Tuberculation serves for protection against predators. Ribbing would stiffen thin shells (against impact and predators?) and could also be related to streamlining, camouflage and transport of chamber liquid. Highly ornate forms displaying great variations are poor swimmers. The ventral groove and "solid" and "hollow" keels protect the siphuncle which is firmly attached to the shell by "horny" lamellae and membranes. The floors of keel and tubercles protect the phragmocone from the inflow of water after breakage of these projections.

The septum of Ammonitina is thinner than in Lytoceratina and Nautilus. Approximated septa are always thickened and are probably built at a reduced rate when normal shell growth has diminished or ceased. Septal corrugation and fluting strengthen the phragmocone wall and body chamber septum against implosion by hydrostatic pressure. The septal lobe of Lytocerataceae also strengthens the septum.

The strength of the siphuncular tube against explosion is estimated from the measurements of its radius and wall thickness. Bathymetric inferences from the strength estimates are 
compatible with previous estimates based on ecologic evidence: Lytocerataceae and Phylloceratidae resemble presentday Nautilus; tube strength decreases ontogenetically in the Ammonitina so that the adult animal could generally not withstand the pressure at more than $100 \mathrm{~m}$ depth. Thickness of the septum usually varies with the strength estimate of the siphuncular tube. The consistently ventro-marginal position of the siphuncle may function to increase the rate of liquid extraction from the lowermost chambers where it would be immersed, i.e. serving rapid buoyancy control; liquid in this position would also improve stability.

Maturation of medium-sized Ammonitina apparently takes place after 4 to 6 years; growth is possibly more rapid in small males (microconchs). The adult animal may live for several more years.

\section{A. Introduction}

In recent years our understanding of the function of septate cephalopod shells has advanced rapidly through observations and experimentation on living Nautilus and Sepia, especially by Bidder (1962), Denton and GilpinBrown (1961, 1963, 1966), and Collins and Minton (1967); investigation of the microstructure and isotope chemistry of present day and fossil shells particularly by Mutvei (1964a, b, 1967), Eichler and Ristedt (1966), Birkelund (1967), Birkelund and Hansen (1968), Erben, Flajs and Siehl (1969), and Stahl and Jordan (1969); the construction of shell models by Reyment (1958); and geometric analysis and the application of computer models by Raup (1966, 1967), and Raup and Chamberlain (1967). I have explored the interrelationship of shell form with the septum and with ornament in the ammonites (Westermann, 1958, 1966). The diversity of sex dependent adult modifications has become evident from the studies of Lehmann (1966, 1969), Makowski (1963), Palframan (1966, 1967), Callomon (1963, 1969), Cope (1967), Cobban (1969), Westermann (1964, 1969b), Zakharov (1969) and others.

This paper is concerned with the functions of shell shape, ornament, septum and siphuncle of adolescent and mature ammonoids, in which they remain poorly understood, although less so than in the non-ammonoid Palaeozoic ectocochliates, according to reviews by Donovan (1964) and Teichert (1967). Analytical work on shell form now in progress by $\mathrm{Mr}$. $\mathrm{R}$. Vicencio of my laboratory may throw new light on these problems in the ammonites.

I am grateful to Dr. D. H. Collins, Royal Ontario Museum, Toronto, for the loan of several well preserved specimens and for his valuable comments. Professor R. A. Reyment, University of Uppsala, and Dr. A. Bidder, University of Cambridge have critically read the manuscript and furnished much advice. I thank Dr. J. E. Mills-Westermann for editorial assistance. Financial aid was received from the Geological Survey of Canada and the National Research Council. 


\section{B. Material}

The specimens examined are from the collection of the Geology Department, McMaster University (McM) and of the Department of Invertebrate Palaeontology, Royal Ontario Museum (ROM). Measurements were performed with optical micrometers, in order to observe both the mode and extent of test preservation, under low-power light microscopy on acetate peels from transverse and median sections, supplemented by thin sections, and by direct observation of the rough-polished sections. Comparisons of the data of test and siphuncular wall thickness were made using two or sometimes all three preparations.

The present observations on very restricted material of nautilids, phylloceratids, lytoceratines, and ammonitines, largely selected due to availability of well preserved specimens, are intended only as a preliminary survey for more extensive systematic studies in the future.

The specimens are listed below, numbered as in the diagrams:

ORDER NAUTILOIDEA, Superfamily Nautilaceae:

1a, b. Nautilus pompilius Linné. Recent [locality unknown].

2. Eutrephoceras dekayi (Morton). Upper Cretaceous; Black Hills, South Dakota, McM K343.

3. Cenoceras inornatus (d'Orbigny). Middle Jurassic; Goslar, N.W. Germany, McM J485.

\section{ORDER AMMONOIDEA}

Suborder Phylloceratina

1a. Phylloceras cf. P. heterophyllum (Sowerby). (?Toarcian) Jurassic; N.W. Germany, McM J1488.

1b. $\quad P$. cf. $P$. heterophyllum (Sowerby). Toarcian; Whitby, England, ROM 2005L.

2. Calliphylloceras sp. Howelli Zone, Aalenian; Wide Bay, Alaska Peninsula, McM J1280.

Suborder Lytoceratina

1a. Lytoceras batesi Trask. Lower Cretaceous; Cottonwood Creek, California, ROM 3588.

1b. L. cf. L. cornucopiae (Sowerby). Toarcian; Ilminster, England, ROM 2136L.

2. Pseudophyllites sp. Upper Cretaceous; Fossil Beach, Vancouver Island, McM K80.

3a, b. Scaphites cf. S. hippocrepis (Dekay). Upper Cretaceous; Black Hills, South Dakota, a, McM K66; b, ROM 26029.

Suborder Ammonitina

1. Asteroceras sp. Sinemurian; (?) N.W. Germany, McM J1489.

2. Dactylioceras cf. D. commune (Sowerby). Toarcian; ?Whitby, England, McM J20.

3. Grammoceras doerntense (Denkmann). Upper Toarcian; Dörnten, N.W. Germany, McM J411.

4. Erycitoides howelli (White). Howelli Zone, Aalenian; Wide Bay, Alaska Peninsula, McM J1242-1. 
5. Sonninia (Fissilobiceras) zitteli (Gottsche). Sowerbyi Zone, Bajocian; Arroyo Blanco, Mendoza, Argentina, McM J1322-16.

5b. S. (Papilliceras) espinazitensis (Tornquist). Sauzei Zone, Bajocian; Charahuilla, Neuquén, Argentina, McM J1311-3.

6a. Stephanoceras (Normannites) orbignyi (Buckman). Humphriesianum Zone, Bajocian; Goslar, N.W. Germany, McM J427.

6b. $\quad S$. (N.) quenstedti (Roche). Humphriesianum Zone, Bajocian; Alfeld, N.W. Germany, McM 1490.

7. Chondroceras (Defonticeras?) submicrostoma (Gottsche). Middle Bajocian; Sierra de Reyes, Mendoza, Argentina.

8. Perisphinctes (Dichotomosphinctes) cf. P. felixi (Aguilera). Kimmeridgian; Los Alamitos, Sierra Catorce, San Luis Potosi, Mexico, McM J1492.

9. Taramelliceras costatum (Quenstedt). Oxfordian; Swabian Jura, Germany, McM J1121.

10a-d. Placenticeras whitfieldi Hyatt. Campanian; Lethbridge, Alberta, McM K36, K118, and K90.

11. Ludwigia bradfordensis (Buckman). Murchisonae Zone, Aelenian; Horn Park, Dorset, England, McM J1493.

\section{Shell Form}

1. WHORL SECTION AND COILING

The most common ammonoid sections are ovate and ogival (like a gothic arch), both either with or without keel and associated ventral structures, e.g. sulci. In ovate sections, ranging from compressed to depressed, the flanks and venter closely follow a catenary (suspended chain curve); a catenary, of all curves having the same perimeter, has the lowest centre of gravity, thus economizing test and increasing stability of the conch by separating the centres of gravity and buoyancy (see Trueman, 1941; Raup and Chamberlain, 1967). Ogival sections are simple modifications of ovate sections, arrived at by omission of a central (axial) part of the curve; a series of shapes can be derived geometrically by varying the elongation and lateral overlap of two identical catenaries from almost total to little overlap, resulting in increased compression and fastigation. The functional differences between these shapes and their modifications are poorly understood at the present time and must be examined in conjunction with coiling, rate of expansion and even with ornament.

The interrelationships of whorl section, degree of involution (i.e. distance from coiling axis) and expansion rate have been studied using models as well as measurements of specimens by Raup (1967) and Raup and Chamberlain (1967). As can be expected, because of partial correlation of these parameters, the more compressed and faster expanding whorls tend to be more involute than depressed and slowly expanding whorls. More surprising are the results of their calculations using models relating mass of test to total volume, i.e. buoyancy. Highest efficiency of test is said to be achieved in slowly expanding shells of average coiling. However, stability of the shell against rolling and turning on itself increases with the 
expansion rate, resulting in shortening of the body chambers, and with more evolute coiling. Raup and Chamberlain (1967, p. 64) conclude that the "observed distribution of ammonoids therefore does not appear to represent the optimization of any single functional factor but rather is a geometric region which minimizes several geometric problems faced by the ammonoids". However, the models are restricted to circular and elliptic whorl sections without the dorsal shell and are not strictly applicable to actual ammonoid shells, including Lytoceratina (see Chapter D). Stability against turning on itself is interpreted by Chamberlain (personal communication) as a limiting factor counteracting the jet propulsion of the hyponome; it is, however, impossible to include in any calculation the behavioural change of attitude of the aperture. Furthermore, all considerations assuming constant growth rates should be applied only to immature shells because of the widespread prominence of adult modifications.

Adult modifications of whorl section and coiling most commonly manifest themselves by rounding and uncoiling (egression of the umbilical seam) of the adult body chamber to varying degrees and in diverse ways. Modifications are usually more prominent in the small male shells, the microconchs, and most strongly developed in either extremely globose or compressed-oxycone shells. Here the umbilical seam egresses rapidly, often resulting in "elliptical" coiling, and the section tends to become ovate or rounded due to reduction of (relative) width growth in the globose and of height growth in the compressed-oxycone forms where the ventral fastigation or keel may also disappear. This results in a lowering of the centre of gravity and thus in an increase in stability and, for the globose shells, probably also in better streamlining. In contrast, the larger female shells, the macroconchs, become modified usually less markedly and more gradually, particularly in the oxycone forms where the umbilicus may become (relatively) narrower and deeper although ventral rounding is usually present. It is possible that the development of an umbilical wall is related to the attachment of the retractor muscles (Jordan, 1968; Westermann, 1969a), and probable that streamlining was increased by narrowing the umbilicus (see Kummel and Lloyd, 1955). Stability and streamlining are also dependent on the absolute size of the shells with the smaller forms needing more marked modifications under similar conditions (current, wave action, etc.) of the sea. This would assume a change of habitat of the adults from that of the immature animals, i.e. from low to high turbulence habitat. In some sphaerocones [otoitids, sphaeroceratids] both dimorphs become strongly modified, and in Scaphites s.l. a complete series is known ending in the detachment of the entire body chamber in the "heteromorphs".

Other important dimensional adult modifications of the body chamber are the frequent reduction in the expansion rate which is especially marked in the sphaerocones, e.g. Chondroceras (Fig. 1 and see Trueman, 1941, Fig. 4) and the very common reduction in angular length (reviewed by Huf, 1968; the inference of Trueman, 1941, that the body chamber length in Promicroceras is constant throughout growth was based on in- 


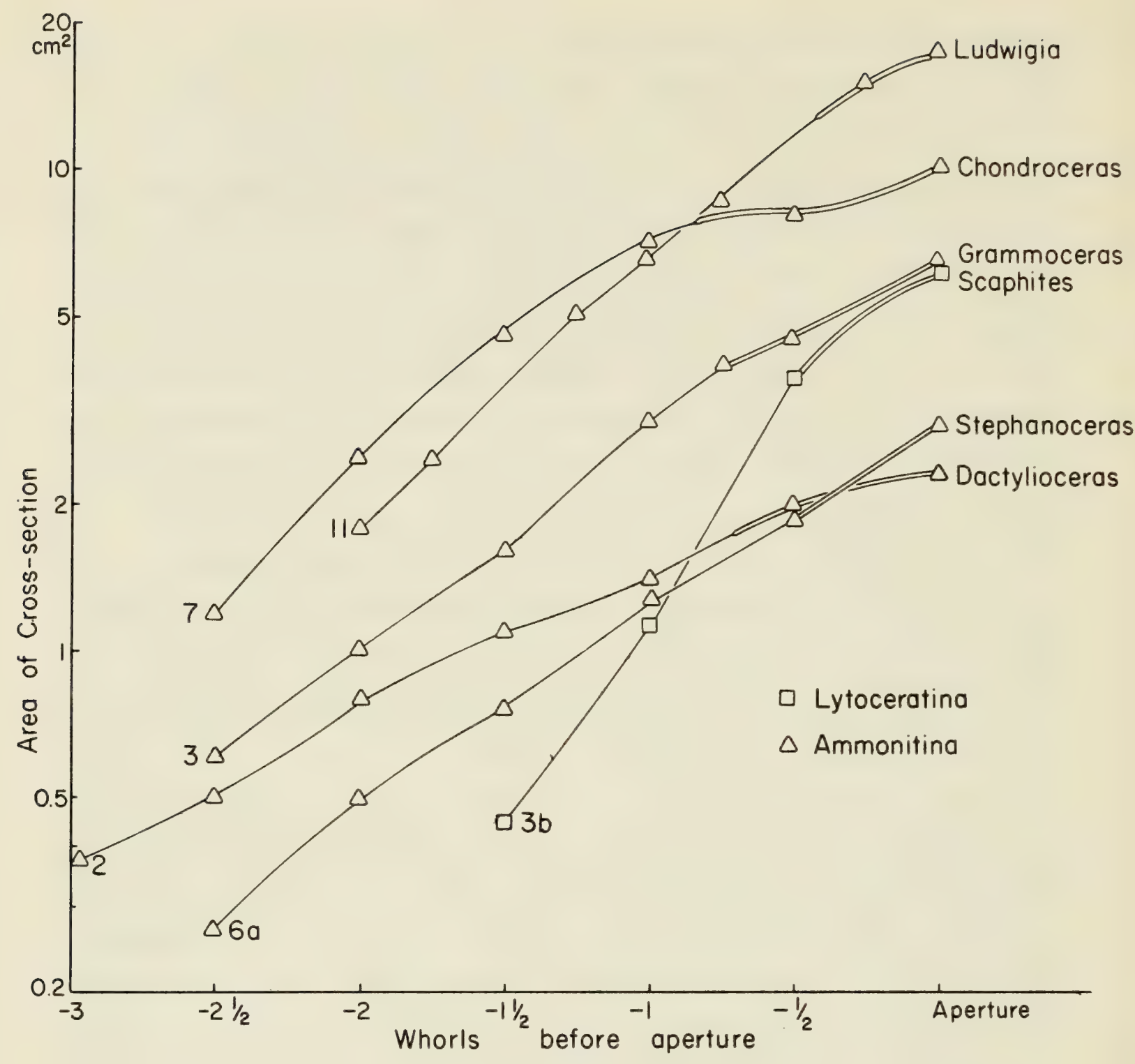

Figure 1. Ontogeny of the area of cross-section for the last two to three whorls of complete shells; logarithmic plot of area at $180^{\circ}$ (half-whorl) intervals from the aperture. Double lines indicate body chambers; numbers refer to species listed under "Material" (B).

sufficient data). Both result in a decrease of the body chamber/phragmocone volume ratio (see Chapter F). Other features, such as dorso-lateral swellings of the body chamber in Scaphites (interpreted as "brood pouches" by Cobban, 1969) are restricted to female shells. The function of well-rounded ovate to sub-circular whorl shapes without ornament, as in present day Nautilus, has long been interpreted as preventing implosion of the phragmocone, thus allowing a deep habitat (see Spath, 1919); and its occurrence in most Lytoceratina and some Phylloceratina is here at least partially interpreted in this way. One may also speculate that the majority of shells with other whorl sections, such as subrectangular and subquadrate shapes, including those seen in many phylloceratines, have derived their resistance against implosion from corrugated and fluted septa (see Chapter E). 


\section{ORNAMENT}

Ribs or costae, which are plications of the shell wall usually running more or less parallel to the growth lines, have usually been interpreted as strengthening the relatively thin shell (see Spath, 1919). In order to prevent implosion under hydrostatic pressure, the strength of plication could be expected to correlate with the relative "flatness" of the flanks, i.e. the degree of compression in species showing a broad range of morphological variation. However, the more inflated (and evolute) whorls bear the strongest ribbing as expressed in my (1st) Buckman Law of Covariation (Westermann, 1966; Raup, 1967). Protection against impact with the rocky sea bottom in turbulent water and/or attack by smaller predators (such as crustaceans) of the often nectobenthonic (and shallow-water) animals (see Chapter I) seems another possible and perhaps more probable function of ornament; this would explain also the fact that large shells, i.e. the variocostate macroconchs (females) of Callomon (1963), often become smooth at maturity when the wall has gained sufficient thickness. Chamberlain is presently also investigating the possibility that certain forms of ribbing decrease drag under conditions of turbulent flow, thereby enhancing streamlining. Other explanations may include camouflage (but unlikely in those showing colour-banding), and increase of the inner surface of the camerae for better liquid transport to the marginal siphuncle ( see Chapters $\mathrm{G}$ and $\mathrm{H}$ ). While the general direction of the ribs may be explained by the outline of the peristome (as evident from the growth lines), the functional meaning of the division into primaries and secondaries in different but usually consistent modes, e.g. intercalation, bundling or fasciculation, is not understood. Yet the repeated phylogenies of certain rib developments indicate functional adaptations. The common division of ribs may simply be due to the increase of circumference with increasing radius; a point of rib division would also appear to be a mechanically good location for a lateral tubercle which may exert localized stress on the shell (see below).

The common mid-ventral interruption of ribbing probably serves the better attachment of the siphuncle (see Chapter F). This becomes apparent when the interruption is essentially restricted to the internal mould of the phragmocone and the beginning of the adult body chamber (Hölder, 1954; Westermann, 1954). A.deep sulcus appears to be for the protection of the siphuncle which is thus "withdrawn" from the periphery.

Tubercles, particularly lateral and ventrolateral spines, almost certainly functioned as protection against predators. They are usually situated on the maximal whorl width and/or on the shoulders. Their internal thickening, most often by secondary test (producing conellae during diagenesis, Figs. 4, 5; Hölder, 1952) would strengthen them against breakage. Long spines are often hollow with a floor of secondary test (Westermann, $1969 \mathrm{a}$, pl. 2) protecting the animal against injury of the mantle and the phragmocone against inflow of water in case of tubercle breakage. Thus these secondary structures, while influencing buoyancy, were not causally related to buoyancy regulation as apparently believed by Teichert (1967, 
p. 204). Infraspecific variation of ornament was, however, frequently so strong that its function in these instances could hardly have been essential to survival or even markedly selective; spines may be present or absent and ribs may vary greatly in strength and density (Westermann, 1966) (see Chapter C4). Regarding variation in ribbing, a morphological series can often be observed in the Hildocerataceae ranging from simple dense ribs to fasciculate ribs to raised bullae-like bundling loci with irregular ribs to bullae or strong tubercles on primaries with irregular secondaries.

\section{KEEL}

Keels are usually, but by no means always, associated with compressed or at least planulate shell form. They are believed to improve streamlining (Spath, 1919) and could possibly help the animal to steady itself by sinking in soft sand or mud; Nautilus sometimes blows a little hollow in the sand with its funnel to produce a similar effect (A. Bidder, in litt.). Keels probably functioned also as protection, particularly of the siphuncle, against predators and damage by impact with an obstacle (see Chapter C2). This conclusion is based on structural design: the keel is either (1) rarely (and/or primitively) "open" with only a slightly thickened wall enclosing the siphuncle, such as in some early Jurassic arietitids (Hölder, 1952, p. 27); (2) "solid" with much thickened wall usually incorporating secondary shell layers, such as in Leioceras; or (3) "floored" and "hollow" (Hohlkiel) with a space between the wall and the secondary test, i.e. the floor which may comprise several layers (Figs. 4, 5). In "solid" and "floored" keels, the keel may be damaged without injury to the siphuncle and inflow of water. The keel floor discontinues at the beginning of the body chamber. All intermediates between these types occur, among related species as well as in the ontogeny of the same shell (e.g. Sonniniidae). Just as in the tubercles, the development of a separate floor appears to be largely correlated with the height of the structure resulting in economy of test in prominent keels and preservation of buoyancy. (Again, the floor does not serve the lowering of buoyancy, see Teichert, 1967.)

\section{INTERRELATION BETWEEN SHAPE AND ORNAMENT}

Whenever the infraspecific variations of all principle surface features are examined simultaneously, it is found that the more involute and compressed forms are less ornate than the more evolute and inflated forms. This applies to Ceratitina, Ammonitina and probably also to ornate "heteromorph" Lytoceratina; it has been called the (1st) Buckman Law of Covariation (Westermann, 1966). Buckman (1892, p. 313) was the first, according to my knowledge, to recognize this interdependence; yet, although he considered all specimens connected by a complete series of intermediate forms as probably belonging to a single "biospecies," he placed them in a multitude of new species. Reasons for the covariation remain unknown. Some ecological conclusions are, nevertheless, possible. Many ammonoid shell populations varied from poor to good efficiency of 
streamlining (see Kummel and Lloyd, 1955); species varying in this manner are therefore inferred to have been poor swimmers (Westermann, 1966).

\section{APERTURE}

Immature apertures are rarely preserved, probably because their test is thin and fragile. In the majority of Ammonitina, the adult aperture is strengthened by marked internal thickening of the test (marking a constriction on the internal mould) with the exception of the macroconchs (female shells) of a few genera which exhibit "unlimited growth" (see Chapter G). Apertural modifications of shell morphology have recently attracted much attention in studies of sexual dimorphism. Ever since the Toarcian (Lehmann, 1969), apertures of the microconchs (male shells) usually bear projections, such as lateral lappets of different sizes and shapes, a single ventral lappet, or a rostrum or horn. Spoon-shaped horns may have contained the spadix (Cope, 1967) or, as Dr. A. Bidder informs me, more probably a median glandular modification equivalent to Van der Hoeven's organ (or Owen's organ, if female). Planulate and sphaerocone shells usually have smooth or concave ventral margins which sometimes, together with exceptionally large converging lateral lappets, outline a round hyponomic opening, and their aperture may be almost occluded (Westermann, 1954). Most discoidal shells bearing lateral lappets have in addition a ventral tongue-shaped projection. Long ventral rostra (suggesting a paired propulsive mechanism?; A. Bidder, in litt.) and horns occur mainly together with straight or sinuous lateral margins. The occluded apertures are obviously a "specialized" feature preventing macrophagous predation, but are not "primitive" as suggested by Donovan (1964). The peristomes of the much larger (X2 to X6) macroconchs have no or minimal projections, but may be flared or collared.

The peristomal thickening of the test, due to continued secretion after longitudinal growth had ceased, gave protection against predators (and struggling prey?) and impact. Healed injuries of the immature shell have frequently been observed, although not as often as in Recent Nautilus (Eichler and Ristedt, 1966, p. 177; and from my inspection of shells collected by Prof. B. F. Glenister); but I have never seen an injured (and healed) adult peristome. The function of the diverse apertural shapes, however, remains unknown. All grades of apertural and, often concurrent, size differentiation of the sexes occurred, from almost undetectable to very pronounced even within a single family (Otoitidae; see Westermann, 1964), reminding us of similar size differentiation in the living coleoids (see Westermann, 1969b, p. 19). Ecological (or behavioural) differences must be inferred for the adults displaying strong shell dimorphism in absolute size, whorl section, coiling, ornament and aperture.

It is probably significant that in contrast, nautilids, lytoceratines and phylloceratines (Howarth and Donovan, 1964) have weak shell dimorphism if any and no significant adult modifications. 

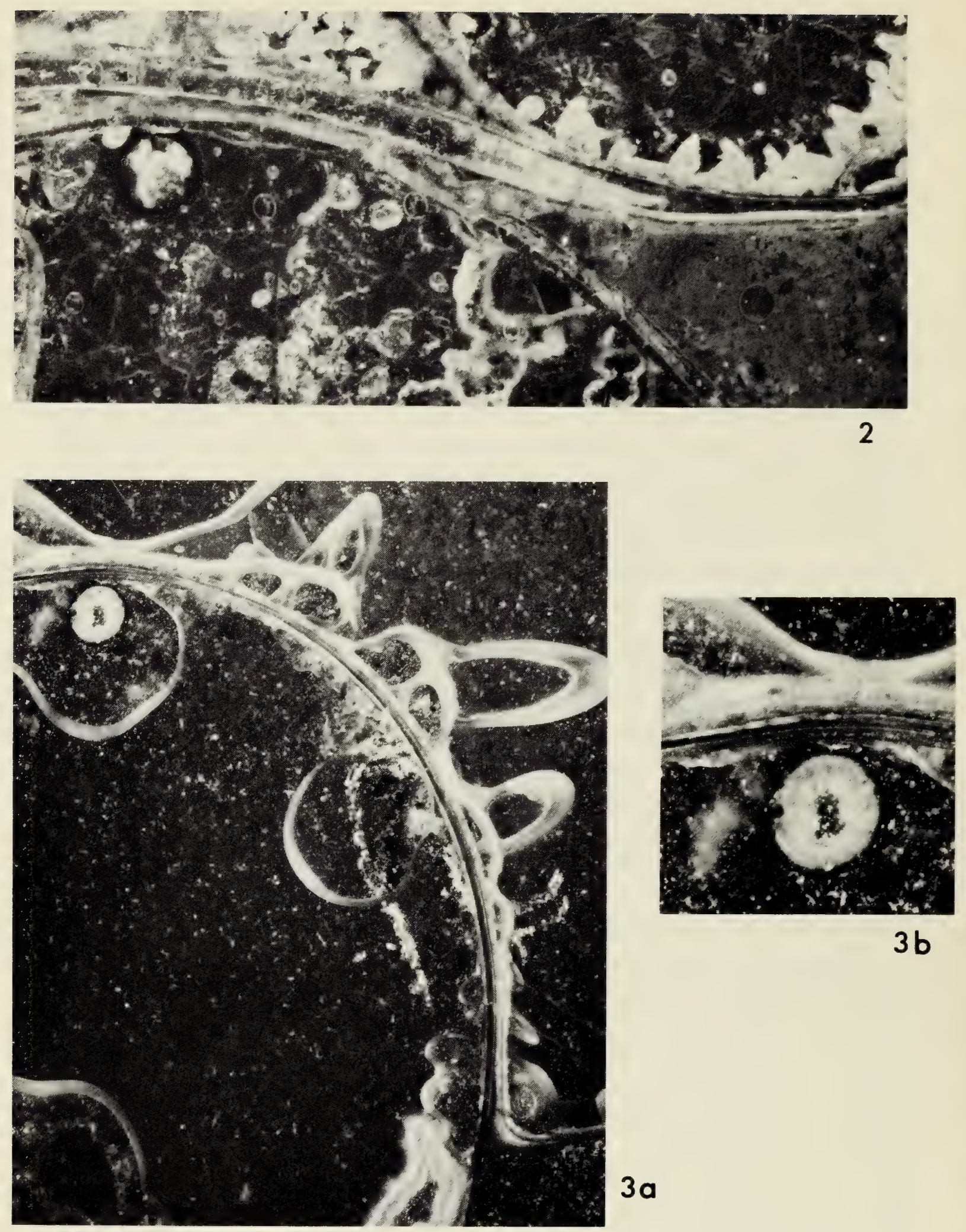

$3 b$

Figures 2-3. The dorsal wall and siphuncular tube in Lytocerataceae; incident light on cross-sections; nacreous layers of dorsal wall partly dissolved away during diagenesis.

2. Lytoceras batesi Trask, X 22.

3. Pseudophyllites sp. a, umbilical wall partly dissolved away during diagenesis, $\mathrm{X} 10 ; b$, enlargement of siphuncular tube with ventral and dorsal walls, X 20. 


\section{Structure of the Shell Wall}

Recent studies have concentrated on the earliest growth stages mainly of Ammonitina, a few Lytoceratina [Saghalinites, Scaphites] and a single genus of the Phylloceratina [Hypophylloceras] (Palframan, 1967; Birkelund, 1967; Birkelund and Hansen 1968; Erben et al., 1969). Apparently adult Ammonitina [Promicroceras, Quenstedtoceras "and other Jurassic ammonites"] were examined by Mutvei (1967).
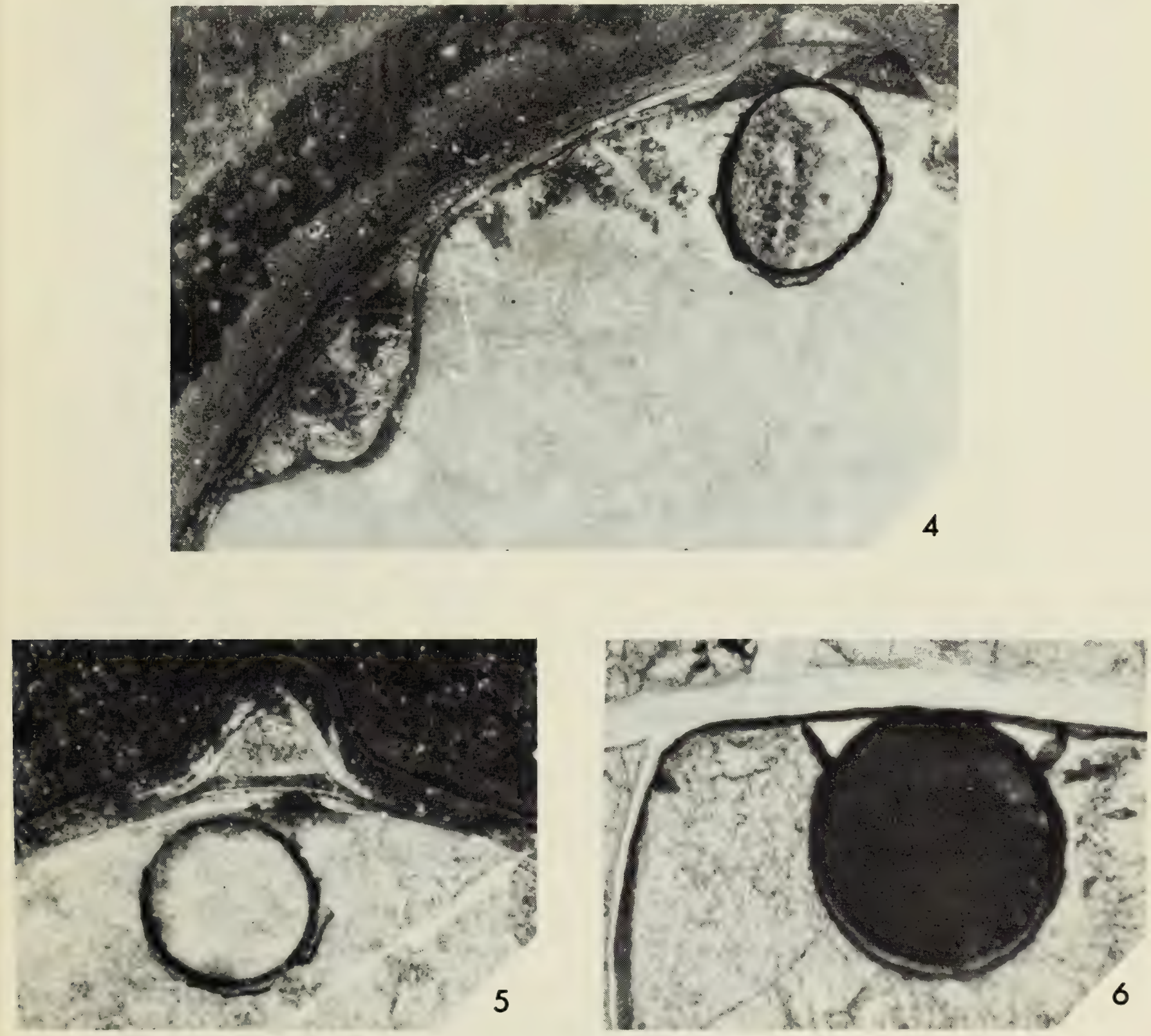

Figures 4-6. The siphuncular tube and ventral shell structures in Ammonitina; incident light on cross-sections.

4. Sonninia zitteli (Gottsche), with keel floor ("hollow keel") consisting of several layers one of which is continuous along the flank; they are partly recrystallized forming two conellae; siphuncular wall distorted, with exfoliated outer membrane. X 9.

5. Sonninia espinazitensis (Tornquist), with layered discontinuous keel floor ("hollow keel") and siphuncular tube; floor recrystallized forming a conella and siphuncular wall with exfoliated outer membrane, X 18.

6. Stephanoceras (Normannites) quenstedti (Roche), with siphuncular tube attached to the ventral wall by short "horny" lamellae, X 90. 
In contrast to most other cephalopod shells, the Ammonoidea shell wall is known to consist only of the outer nacreous layer and the inner, usually thinner, prismatic layer, and has usually been believed to be absent dorsally, "at least in the inner whorls" (Erben et al., 1969, p. 11). However, Birkelund and Hansen (1968, p. 75) reported a thin dorsal shell from mature Saghalinites [Lytoceratina, Tetragonitidae].

Dorsal shell of appreciable thickness is here reported from other Lytoceratina, i.e. Lytoceras, Pseudophyllites, and Scaphites, as well as from Placenticeras of the Ammonitina. The thick prismatic layer continues dorsally almost undiminished in the advolute Lytoceras cornucopiae (Sow.) and L. batesi Trask (Fig. 2), while it thins markedly in the more involutely coiled Pseudophyllites sp. (Fig. 3a). In the involute phragmocone of the "heteromorph" Scaphites ex gr. S. hipprocrepis (Dekay), the dorsal wall is very thin, thickening only one-half whorl before the shell uncoils. It appears, therefore, that the presence of a dorsal shell wall is characteristic for the Lytoceratina (this would then support the classification of the scaphitids in the Lytoceratina as in the "Treatise," rather than in the Ammonitina, as in "Osnovi Palaeontologii") and one may speculate that this is causally related to the repeated appearance of the "heteromorph" branches within this order. Any such hypothesis would, of course, have to take into account the presence of a dorsal wall in at least one genus of the Ammonitina and require much more data from good material.

Another poorly known wall structure is the almost complete internal duplication by secondary test observed by Jordan (1968, p. 37) in Pleurolytoceras and here reported from the hammatoceratid Sonninia (Fig. 4). In the last phragmocone whorl of S. zitteli (Gottsche), one layer of the double-layered keel floor (see Chapter C3) continues to the umbilical seam and along part of the dorsum; in the earlier whorls, however, the keel floor wedges out at the shoulders.

The shallow to deep impressions on the internal wall surface originating from the attachment of different muscles and/or tendons(?), some involving perishable test structures, were recently thoroughly examined by Jordan (1968), and "porous material" has been described underlying the umbilical slope of the shell in Otoitidae (Westermann, 1969a).

\section{WALL THICKNESS}

Thicknesses of the shell wall were measured particularly by Trueman (1941, p. 351 ) to facilitate calculations for buoyancy; however, only the data for Promicroceras and Dactylioceras were published, without indication of the growth stages. Noting the great diversity in the Ammonitina, Trueman reported test/total area ratios in the cross-sections (corresponding to similar volume ratios) from $1: 8$ in Asteroceras, to $1: 11$ in Dactylioceras, to $1: 12$ in Promicroceras, to $1: 14$ in Ludwigia, to 1:30-1:60 in Liparoceras. Reyment (1958, p. 146) recorded measurements from shells preserved in aragonite (as proved by X-ray analysis).

Thickness of the (primary) external shell wall measured near the venter is plotted against diameter of the shell for Nautilus pompilius L. and several Mesozoic nautilids, phylloceratids, lytoceratines, and ammonitines; True- 


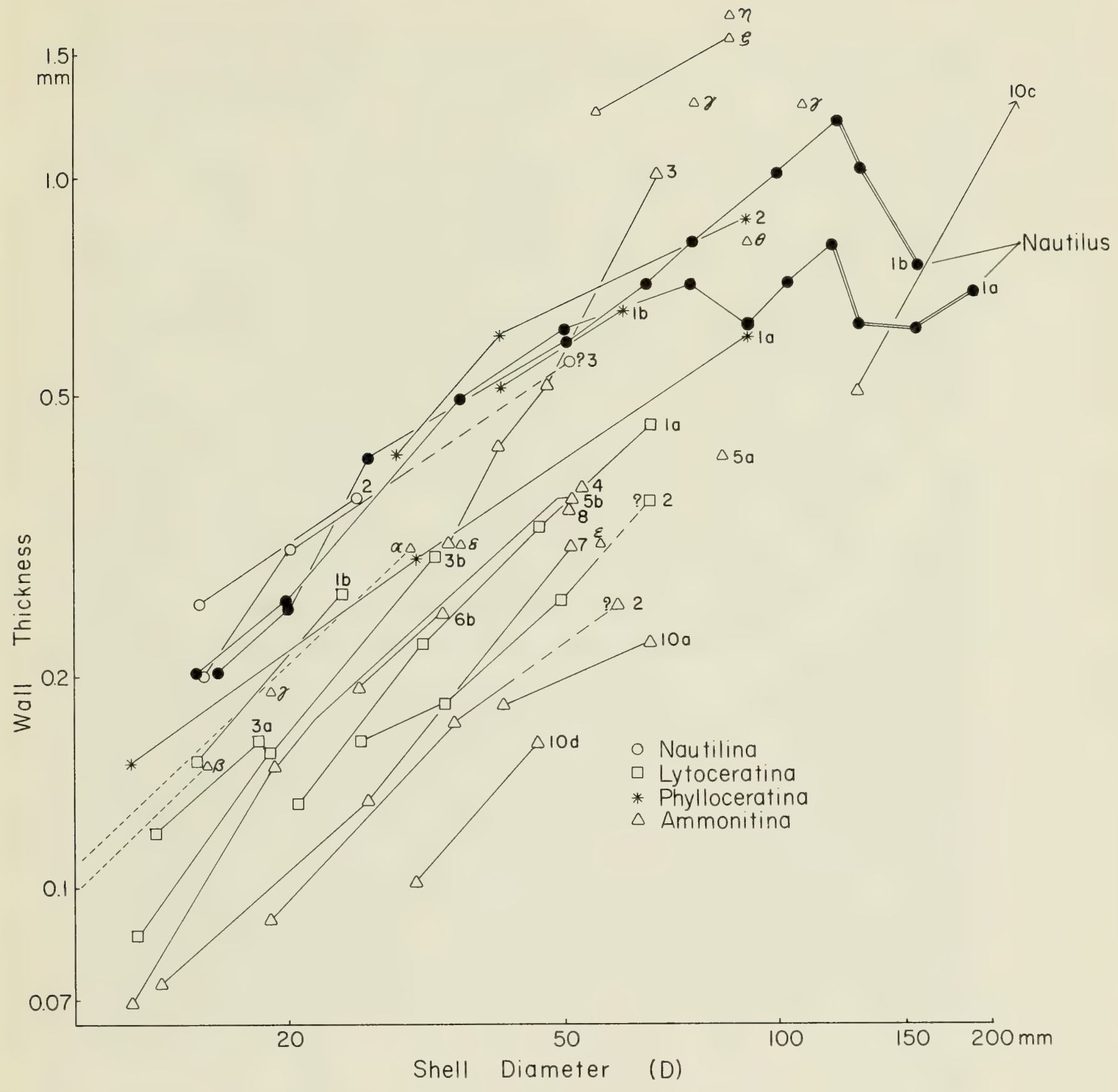

Figure 7. Ontogeny of wall thickness (primary test, measured on venter and on the side of the keel if present); double-logarithmic plot against diameter. Double lines indicate body chambers.

Nautilina (o): 1a-b, present-day Nautilus, 2, Eutrephoceras, 3, Paracenoceras; Lytoceratina $(\square)$ : 1a-b, Lytoceras, 2, Pseudophyllites, 3, Scaphites; Phylloceratina (*): 1a, b, Phylloceras, 2, Calliphylloceras; and Ammonitina $(\triangle):$ 2, Dactylioceras, 3, Grammoceras, 4, Erycitoides, 5a-b, Sonninia, 6b, Stephanoceras, 7, Chondroceras, 8, Perispinctes, 10a-d, Placenticeras; for species see "Material" (B). Data from Trueman $(1941 ; a, \beta)$ and Reyment $(1958 ; \lambda-\theta)$ : $\alpha$, Dactylioceras, $\beta$, Promicroceras, $\lambda$, Craspedites, $\zeta$, Subcraspedites, $\epsilon$, Macrocephalites, 6 , Libycoceras, $\partial$, Speetoniceras, $\theta$, Placenticeras.

Phragmocone wall thickness tends to be greater in nautiloids and phylloceratids than in ammonites, and to be intermediate in lytoceratids. (For larger shells and body chambers see text.) 
man's and Reyment's data are included (Fig. 7). Up to $45 \mathrm{~mm}$ diameter the Nautilidae resemble the Phylloceratidae, both being consistently thicker shelled than the Lytoceratina and Ammonitina; this difference would be enhanced for Nautilus ( +30 to $40 \%$ ) if measurements were taken from the flanks (see also Spath, 1919, p. 120). Among the ammonoids, Lytoceratina tend to have thicker walls than Ammonitina. However, any conclusions must be very tentative awaiting more data from well-preserved (unaltered) shells, and any strength interpretations would have to take into account the complex mechanical relationships with whorl section, coiling, ornament, and septation. Trueman's conclusion (1941), that his shells displayed negative allometry is neither evident from his own scatter diagrams, nor from my new data from the Ammonitina and Lytoceratina.

While allometry of wall thickness becomes increasingly negative for the outer whorls of Nautilus pompilius so that the body chamber wall (in one of my specimens, also the end of the phragmocone) becomes absolutely thinner (there is no danger of implosion of the body chamber), the growth of the ammonoid shell wall continues approximately isometric or positively allometric. The data, although admittedly insufficient, indicate that many walls of ammonoid body chambers are disproportionately thick, especially at the aperture.

Some of Reyment's measurements (1958) from the shell wall of larger ammonites which, he informed me, were selected for their unusually thick shells, particularly those of Libycoceras and Speetoniceras, are greater than those reported here. Reyment's data for Libycoceras were taken from the body chamber (in litt.) while the data for Placenticeras whitfieldi of which I examined similar specimens may include the dorsal wall. Furthermore, diagenetic separation of the shell layers and subsequent infilling with sparry calcite producing an apparently thick shell seems also to be quite common in aragonitic preservation (however, Reyment informed me that $\mathrm{X}$-ray analysis of his shells did not give any evidence of adulteration). Acetate peels or thin sections can be used to recognize this type of preservation.

Since strength of the wall against implosion (by hydrostatic pressure) increases with convexity, the wall of the flattish flanks of compressed shells could be expected to be thicker than their convex ventral portion. This may be the reason for the lateral wall thickening (30-40\%) observed in Nautilus. (Other reasons suggested by A. Bidder, in litt., are the attachment of the retractor muscles and the decreasing rate of growth towards the umbilicus giving more time for nacreous deposit.) However, such thickening is rarely seen in the ammonoids in which the wall is supported by the corrugated and fluted septa which vary in spacing and curvature not only between species but also during ontogeny and between parts of a single suture (see Chapter E). It is therefore probable that the strength of the shell wall (and hence its thickness) is more dependent on this septal support than on its own "shell surface" (vaulted) structure; to obtain calculations of strain limits promises to be highly complex if not impossible. 


\section{E. Septum and Suture}

An array of hypotheses explaining the function of corrugation and marginal fluting of the ammonoid septa includes

A) mechanical:

(1) preventing implosion of the phragmocone wall as well as of the body chamber septum (Pfaff, 1911; cf. Spath, 1919; Westermann, 1956, 1958);

(2) the lobes serving the secure attachment of the body (Spath, 1919);

(3) increasing the overall weight of the shell for buoyancy control (as apparently implied by Reyment, 1958, and Teichert, 1967).

B) physiological:

(1) reflecting the shape of the posterior mantle which may serve for better respiration (Newell, 1949);

(2) increasing the wettable conchiolin surface layer in the chambers for faster liquid transport to the siphuncle to aid in buoyancy control (Mutvei, 1967).

Other speculations are restricted to the fluting, i.e. the septal suture; they are usually either poorly elucidated or not based on hypothetical functions and therefore need not be discussed. Examples are (1) Hyatt's explanation that progressive sutural complication in ammonoids helped to "carry and balance the shell above the extruded parts when the animal was crawling," a mode of life inferred by him from the common presence of a ventral rostrum in the place of the hyponomic sinus in Nautilus (Hyatt in Eastman-Zittel, 1900, p. 544, fide Spath, 1919, p. 70); and (2) Spath's proposal (1919, p. 71) that extreme sutural elaboration such as in Pinacoceras "where the septal edge seems to be complicated beyond utility and mechanical requirements" is due to some sort of over-specialization ". . . generally followed by the extinction of the specialized lineage ..."

According to recent studies by Mutvei (1967) and Erben et al. (1969), the ammonoid septum consists of a single nacreous layer covered on both sides by thin conchiolin membranes; the Nautilus septum comprises the nacreous layer, the prismatic layer, and possibly the "spherulitic-prismatic layer” (Mutvei, 1967, although refuted by Erben et al. 1969, p. 11).

\section{SEPTAL THICKNESS}

Only a few measurements of septal thickness are available (particularly those given by Trueman, 1941, and Reyment, 1958) and these lack information about the growth stage except for diameter. They have been included in the scatter for septal thickness against shell diameter (Fig. 8) for several nautiloids, lytoceratines, phylloceratids, and ammonites. The ammonoid septum thins from its centre towards the margin, at first gently and then rapidly in its fluted periphery. Most of the examined Nautilina resemble closely the Lytoceratina and both taxa have thicker septa than the Ammonitina and Phylloceras. Exceptions are (1) the Jurassic nauti- 


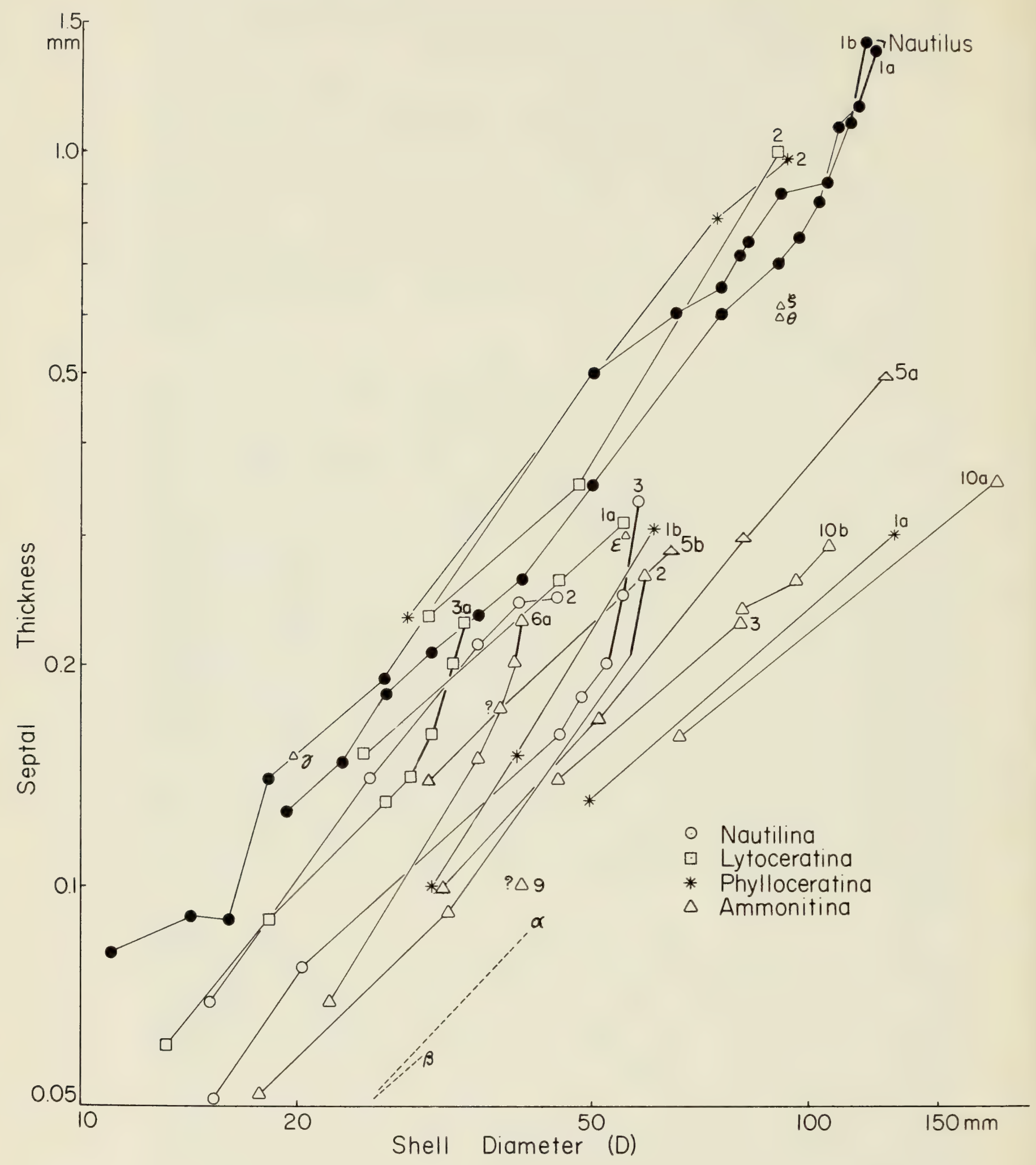

Figure 8. Ontogeny of septal thickness (near centre of septum); doublelogarithmic plot against diameter; thick lines connect approximated septa. Same symbols and numbers as in Figure 7.

Septal thickness tends to be greater in nautiloids and lytoceratids than in ammonitines, but there is much variation. Approximated septa are also much thickened (positive allometry). 


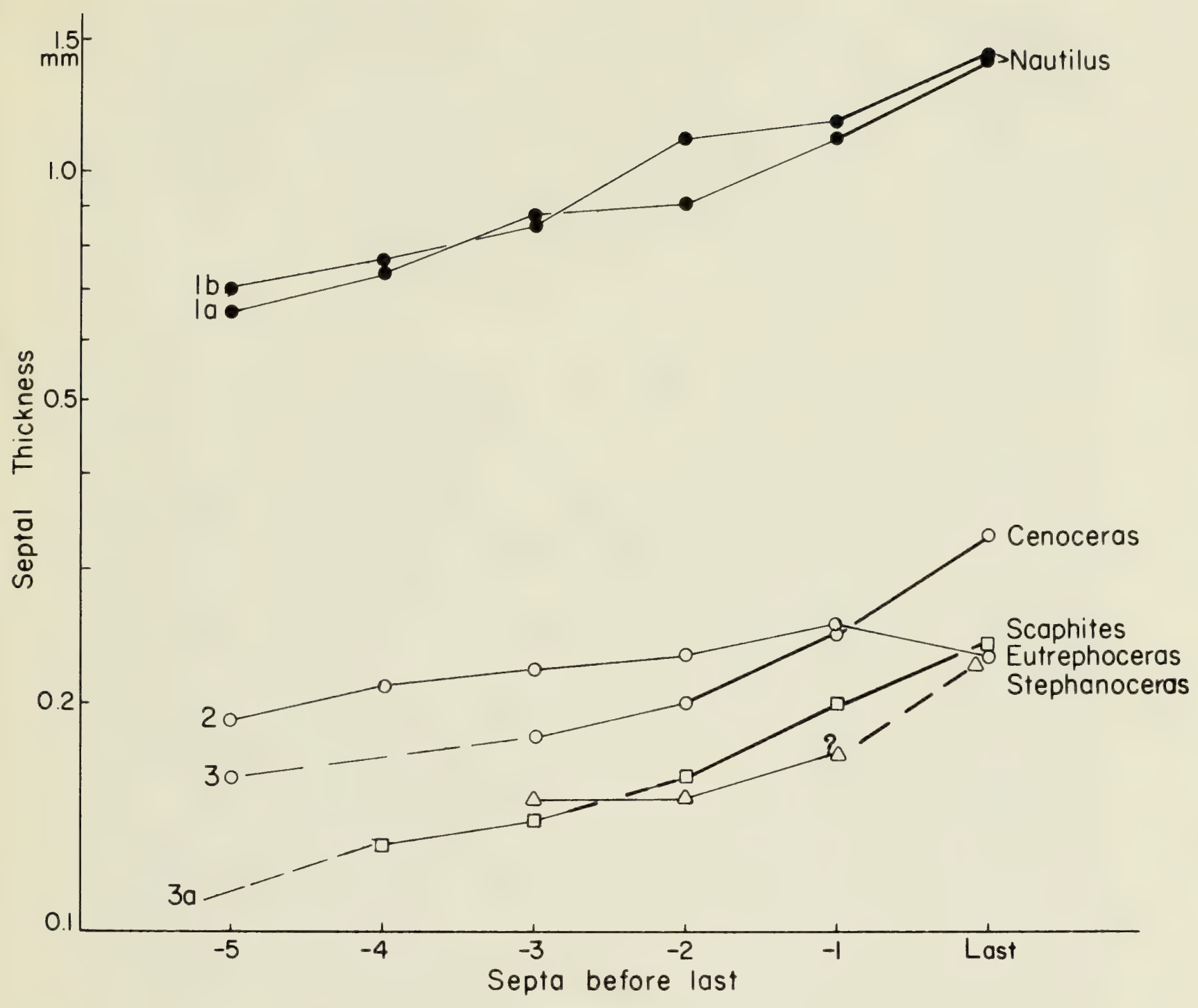

Figure 9. Ontogeny of septal thickness (near centre of septum) for the last six septa; plotted on logarithmic scale against septa in ordinal sequence; thick lines connect approximated septa.

All approximated septa are markedly thickened (positive allometry) indicating adult decrease of growth rate of the shell; Eutrephoceras is immature.

loid Cenoceras which is similar to the Ammonitina (also in the absence of dorsal shell wall!) and (2) Reyment's measurements for the Ammonitina Craspedites, Speetoniceras and probably Libycoceras and Placenticeras. However my own data from the same species (and preservation) of Placenticeras agree more closely with those of other Ammonitina. Ontogenetic development of septal thickness is usually isometric with respect to shell diameter, except for the first 5 or 6 more widely spaced septa of Nautilus which are relatively thinner (probably reflecting their faster secretion in the egg sac in warmer water; see Eichler and Ristedt, 1966).

Adult septal thickening and approximation (Fig. 9) are both most readily explained by deceleration or cessation of normal wall growth, accompanied by increased duration of septal secretion and decreased withdrawal of the body, resulting in relative (angular length) or even absolute shortening of the body. chamber. The modifications of the aperture were 
likely produced at this stage. Peripheral (sutural) simplification of approximated terminal septa is in some way interrelated with their thickening, possibly involving strength in the suture (Pfaff, 1911; Spath, 1919).

While the mechanical strength for the simple nautilid septum undergoing tensile stress only (hydrostatic pressure transmitted through the body) was easily calculated by Pfaff (1911), similar calculations for the highly complex ammonoid septum are incomparably more difficult if not impossible to obtain.

\section{SHAPE}

The complex curvature of Mesozoic ammonoid septa follows different corrugation patterns which are further complicated by the radial increase of amplitudes and wave lengths, and the peripheral fluting. Since the undulations forming the lobes are greater in amplitude than those forming the saddles of the suture, the average curvature is adorally convex (Swinnerton and Trueman, 1918, p. 31). This is apparently the result of a positive pressure differential of the liquid separating the last septum from the animal's body after it has withdrawn (or has been pushed by the liquid) to the next septal position (negative in Nautilus?) (Spath, 1919, p. 27; see Denton and Gilpin-Brown, 1966). This could be achieved by continued liquid secretion after the organic layer upon which the calcareous septum is secreted has been produced (A. Bidder, in litt.). Pfaff (1911, p. 213) had already noted that an adorally convex septum has a higher strength against pressure transmitted through the body than the concave nautiloid septum, since compressional strength of the test is higher (X6) than tensile strength. He stated (p. 217) that the curvatures along the axial lines of the septal undulations ("lobes" and "saddles") are parabolas ("parabolic catenaries"), although evidence is lacking.

The patterns of corrugation and fluting of ammonoid septa suggest "ideal" complex vault structures to a shell-surface engineer (G. Ae. Oravas, personal communication). This was first clearly expressed by Pfaff (1911) who, however, concluded (p. 222) that "the shape of septa and their suture lines is absolutely dependent on the form of the whorl section, decrease or increase in involution, and the strength of the last septum" [translated from German]. Even Arkell (1957, p. 242) supported this view with regard to the septal surface, although Westermann (1956; see also 1958) had demonstrated that different corrugation patterns corresponding to distinct taxa existed for similar whorl shapes and that therefore the septa owe their fluting pattern to whorl shape ("correlated features") and inheritance (for suture see Spath, 1919, p. 28). Arkell's (loc. cit.) arguments directed against Pfaff's assumption of a constant low gas pressure in the chambers while diving have been proved invalid by the recent studies on living Sepia and Nautilus by Denton and Gilpin-Brown $(1961,1966)$. Pfaff's hypothesis that ammonoid septa function (when in last position during growth) as ideal vaulted surfaces to transmit the pressure exerted through the body onto the shell wall is valid at least in part; another function, which seems to have been first suggested by Owen (1843, fide Spath, 1919, p. 119) is probably to strengthen the 
phragmocone against hydrostatic implosion (and breakage by localized stress incurred through predators and impact?) by means of the length increase of the margin (suture) minimizing free-carrying wall areas (hypothesis $\mathrm{Al}$ ). The fluted periphery of the septum is much thinner than the periphery of non-fluted septa so that bulk of the test may be about the same. Thus strength of wall and septum equal to that in the nautiloids can be achieved with a decreased amount of shell material (but see Chapters C1, 2 and D). This contradicts hypothesis A3 that septal corrugation (and fluting) served, at least secondarily, as a means to increase the overall weight of the shell (Reyment, 1958; Teichert, 1967); increase in weight, if at all needed, would have been facilitated more easily by thickening of the test (as in case of adult septa).

The answer to the age-old question as to why ammonoids need folded septa when nautiloids do so well with simple septa is probably to be found in the whorl section: wall implosion of the rounded ovate whorls of nautiloids is prevented largely by the vaulted, shell-surface design of the walls themselves, the septum functioning mainly against pressure transmitted through the soft body; the whorl section of ammonoids usually deviates from a shape effective as a shell-surface, particularly in the flat flanks of compressed shells and the flat venter of strongly depressed or tabulate shells, so that the septum has to support the wall against implosion. Thus one may speculate that the complexity of the ammonoid septum made possible the evolution of the large variety of known whorl shapes; they probably reflect different habits and habitats which may in part resemble those of the living Nautilus.

Quantitative investigations on the degree of interrelationship of septal and sutural patterns with whorl shape are now being carried out by $\mathrm{R}$. Vicencio of my laboratory. Little has so far been added to Pfaff's (1911) and Spath's (1919, p. 28) suggestions regarding the number, position and size of the lobes and saddles. The external (or ventral) lobe is probably related to the marginal position of the siphuncle, appearing first in Bactrites; ventro-lateral and dorso-lateral elements increase in size and complexity with the depression of whorl section; and the presence, number and extent of the secondary umbilical lobes ("auxiliaries") are dependent on the whorl overlap (Westermann, 1956, 1958; Schindewolf, 1961, p. 728; Wiedmann, 1969, p. 572).

The principal attachment of the posterior mantle to the shell in ammonoids was along the gently curved "Haftband-Struktur," the "annulus structure" of earlier authors (Jordan, 1968, p. 34), but not in the lobes (hypothesis A2).

The patterns of septal corrugation and fluting are incompatible with the recent proposal of Mutvei (1967; hypothesis B2) that the resulting increase of the conchiolin membranes covering the septa served for the more efficient transport of cameral fluid to the siphuncle during regulation of buoyancy. The corrugations (lobe and saddle axes) run more or less perpendicularly to the assumed direction of transport, i.e. from the dorsolateral areas of the chambers to the siphuncle; this is particularly evident 


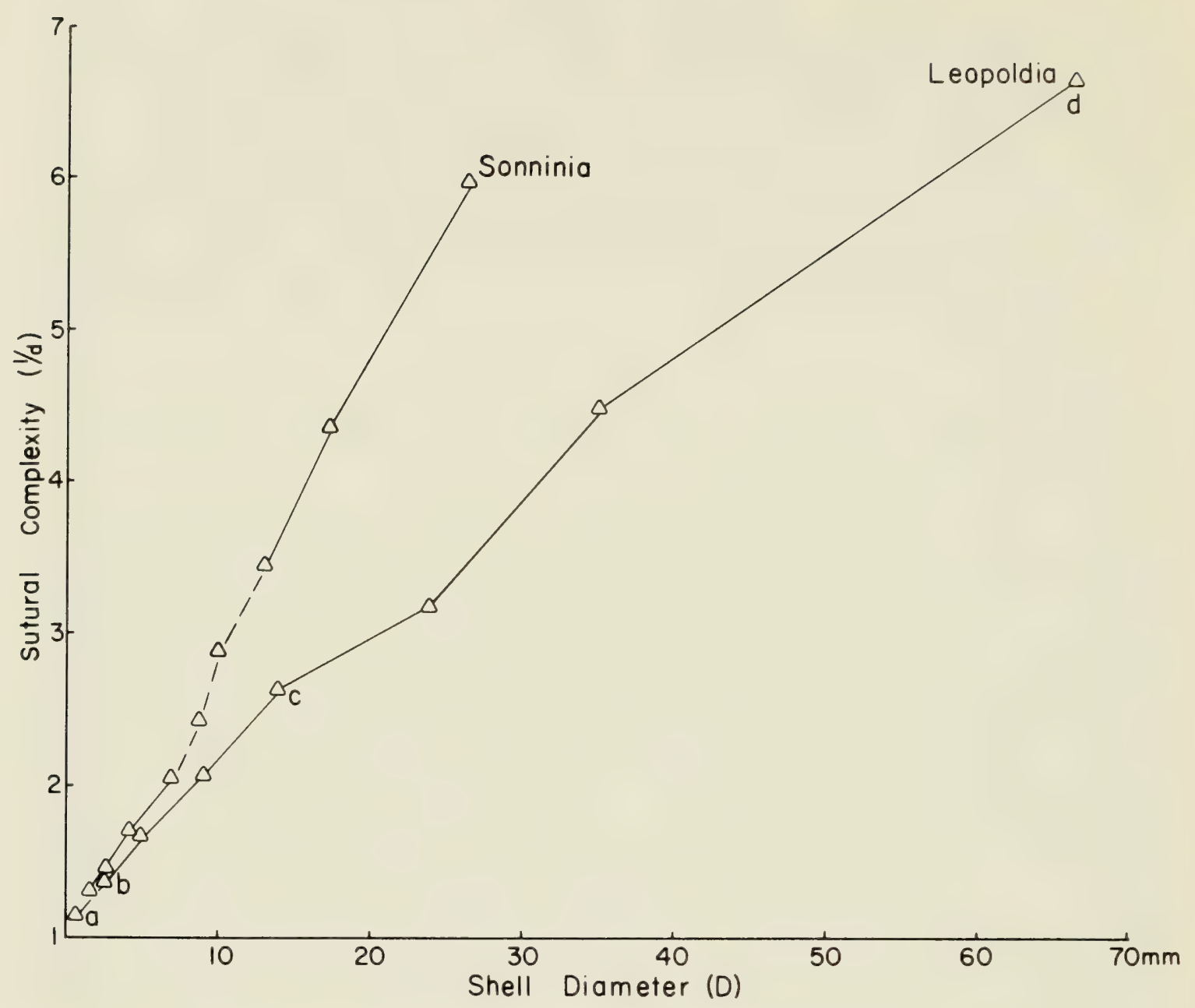

Figure 10. Ontogeny of the sutural complexity index [curvature length (1)/ dorso-ventral distance (d)] for the Ammonitina Sonninia malarguensis (Burckhardt) (McM J 1300-73), Bajocian, and Leopoldia attenuata (Behrendsen) (Museo La Plata 11068), Valanginian-Hauterivian boundary, both from Argentina; measurements from highly magnified cameralucida drawings by A. C. Riccardi. Letters for Leopoldia refer to Figure 11.

The ontogeny of the complexity index follows an almost straight line of different slope.

in compressed and depressed shells, and to a large extent also in planulate shells (see Westermann, 1956, 1958). Therefore the path of transport would not be widened by the corrugations but much extended, and corrugated septa would be less efficient; Mutvei's hypothesis would require corrugations radiating from the siphuncle. The necessary requirements of surface increases are, on the other hand, met by costation, i.e. plication of the shell wall. However, no conchiolin membrane has as yet been observed on the inner shell wall. To the best of my knowledge, no physiological function, such as respiration (Newell, 1949), is known from living cephalopods, which gains from surface increase of the posterior portion of the mantle (hypothesis B1).

The marginal fluting ("frilling") of the septum as seen in the suture consists of up to 3 or even 4 orders of curvature and shows much variation which, as Vicencio informs me, is largely attributable to random ex- 


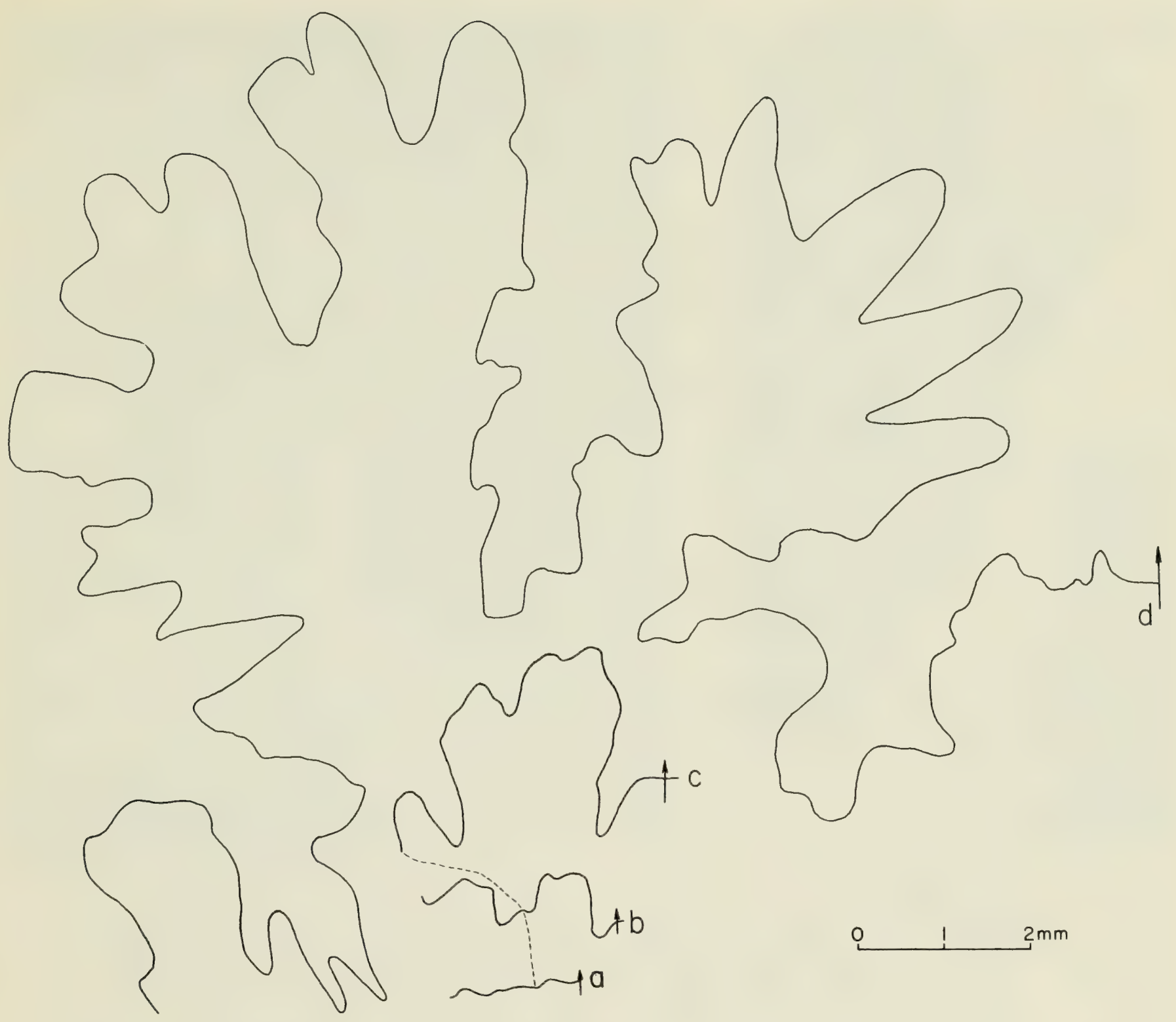

Figure 11. Ontogeny of the external saddle $(\mathrm{E} / \mathrm{L})$ in Leopoldia attenuata (Behrendsen); same specimen at shell diameter $(a-d)$ indicated in Figure 10.

The average curvature radius increases only slightly throughout growth (it remains similar in Sonninia).

tension in meander-fashion of the septal margin. There is a surprising resemblance to the fluted walls separating the septa of the present day Sepia which prevent implosion (see Kälin, 1967, Fig. 19). In 1911 Pfaff observed that the length of the suture increases ontogenetically in proportion to the projected surface of the corresponding septal surface; i.e. approximately with the square of the linear dimensions if septal thickness remains constant (see Fig. 10). He interpreted this as the design mechanically ideal to distribute the body pressure over the last septum onto the thin shell wall. Consequently, the curvature radii of the suture may remain similar during growth, the "frills" of the adult shell approximating the saddles and lobes of the primary suture (Fig. 11), and the diameter of free-carrying areas of the wall may increase little in shells with complex and densely spaced sutures. However, quantitative examinations relating 
sutural complication with septal thickness have not been made. Of interest with regard to the strength of the shell wall against implosion is the inverse relationship between intensity of wall plication (ribbing) and sutural complexity, as sometimes observed by Buckman (1892, p. 313) and Spath (1919, p. 29, 32, 34) (the tentative 2nd Buckman Law of Covariation of Westermann, 1966). Although this apparent negative correlation is probably due to strength compensation by the shell wall, it seems that wall plication is a less important factor than whorl section which is consistently correlated with ornament (see Chapter C4). Concerning the hypothesis of Pfaff (1911) that the loss of strength by thinning of septa (and shell walls) is compensated through the increased complication of the peripheral fluting, the thickness measurements on two species of the ammonite Sonninia (Figs. 7, 8) may be of some significance. S. zitteli (Gottsche), with a complex suture, has thinner septa and a thinner shell wall than S. espinazitensis (Tornquist), which has a simple suture. However, the underlying assumption of equal implosive strength of the two species is, of course, highly hypothetical.

\section{SEPTAL LOBE}

This structure (see "Treatise", p. L97, Fig. 142a, b) is apparently confined to the Lytoceratacea; I have observed it in Lytoceras and in the tetragonitid Pseudophyllites (Fig. 12). The septal lobe is not homologous to "riding" sutures which occur irregularly owing to adult septal approximation (Hölder, 1952, p. 42). The septa of at least the intermediate and outer phragmocone whorls of these lytoceratines project dorsally and adapically into a short truncated subcircular tunnel measuring approximately two-fifths of the whorl diameter. This tunnel divides posteriorly into two narrow and somewhat diverging "lobes" which are attached to the preceding septum along its tunnel entrance, forming the paired septal lobe (appearing as an inverted paired saddle). The suture runs from the septal lobe onto the narrow dorsum of the shell (dorsal shell) forming the internal ("dorsal") lobe (the internal parts of the sutures figured by Schindewolf, 1961, Abb. 4-24, however, do not show the narrow interruption caused by the septal lobe). Since all septa are interconnected by the septal lobes, a septate tunnel is developed along the dorsum. This structure would have contributed toward strengthening the last septum against hydrostatic pressure transmitted through the soft body and perhaps also to the strength of the entire loosely coiled phragmocone.

\section{F. Siphuncle}

The siphuncular tube of ammonoids consists of concentric conchiolin membranes between the septal necks, forming a comparatively thick "horny" tube; the outer "chalky" aragonitic tube of the nautiloids seems to be missing (Mutvei, 1967). Calcareous material reported from the tetragonitid Saghalinites of the Lytoceratina by Birkelund and Hansen (1968, p. 76) is believed to be of diagenetic origin (Erben et al., 1969, p. 44).

Except for the first one or two whorls, the ammonoid siphuncular tube 

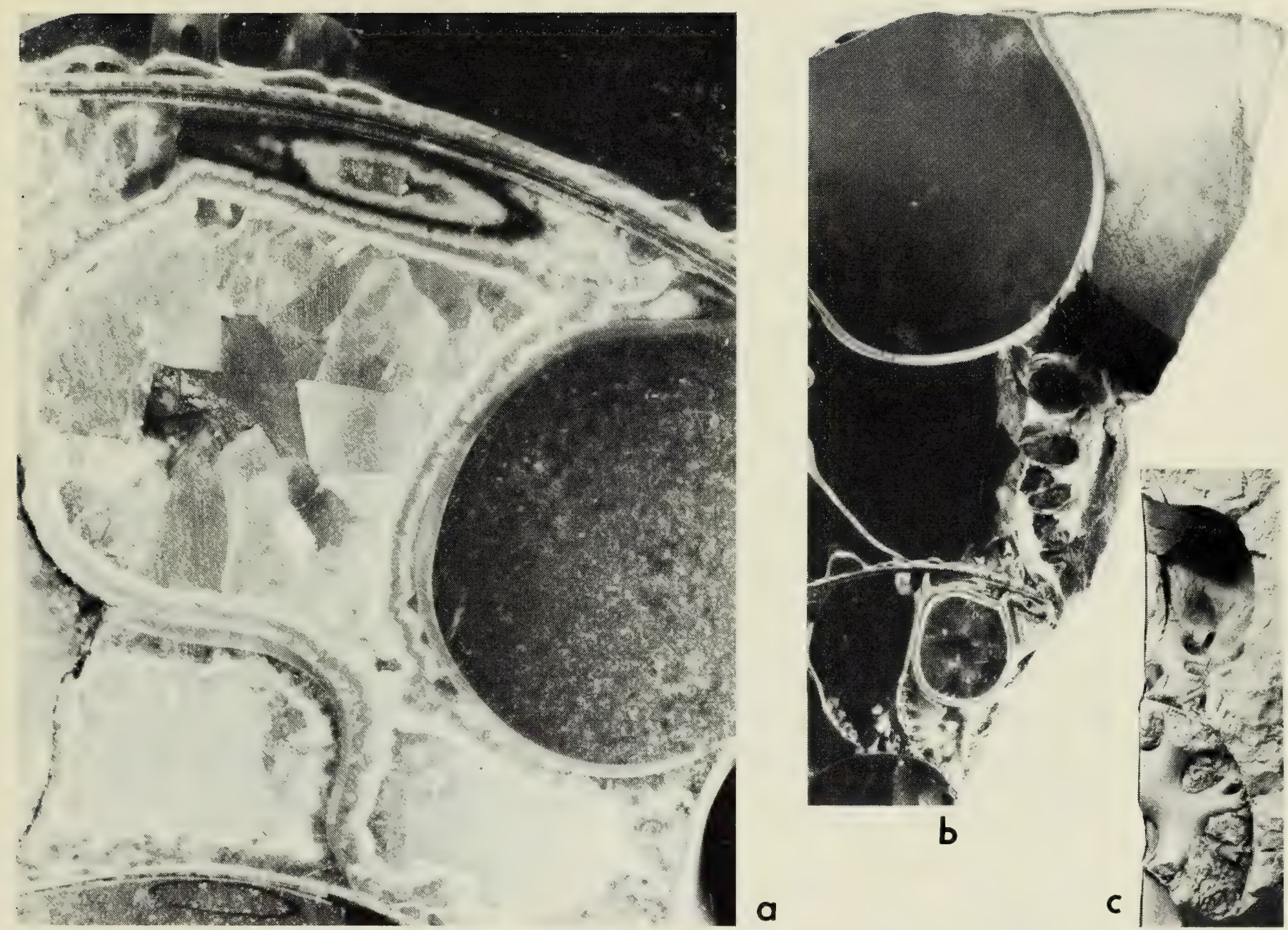

Figure 12. The septal lobe in the lytoceratine Pseudophyllites sp.; incident light. $a$, median section shows the septa forming a dorsal "tunnel", and the ventral and dorsal shell walls, $\mathrm{X} 8.5 ; b-c$, the dorsal "tunnel" with septal lobe developed from the matrix, $(b)$ in lateral view of median section, $\mathrm{X} 1.9$, and $(c)$ in apertural view, $\mathrm{X} 1.5$.
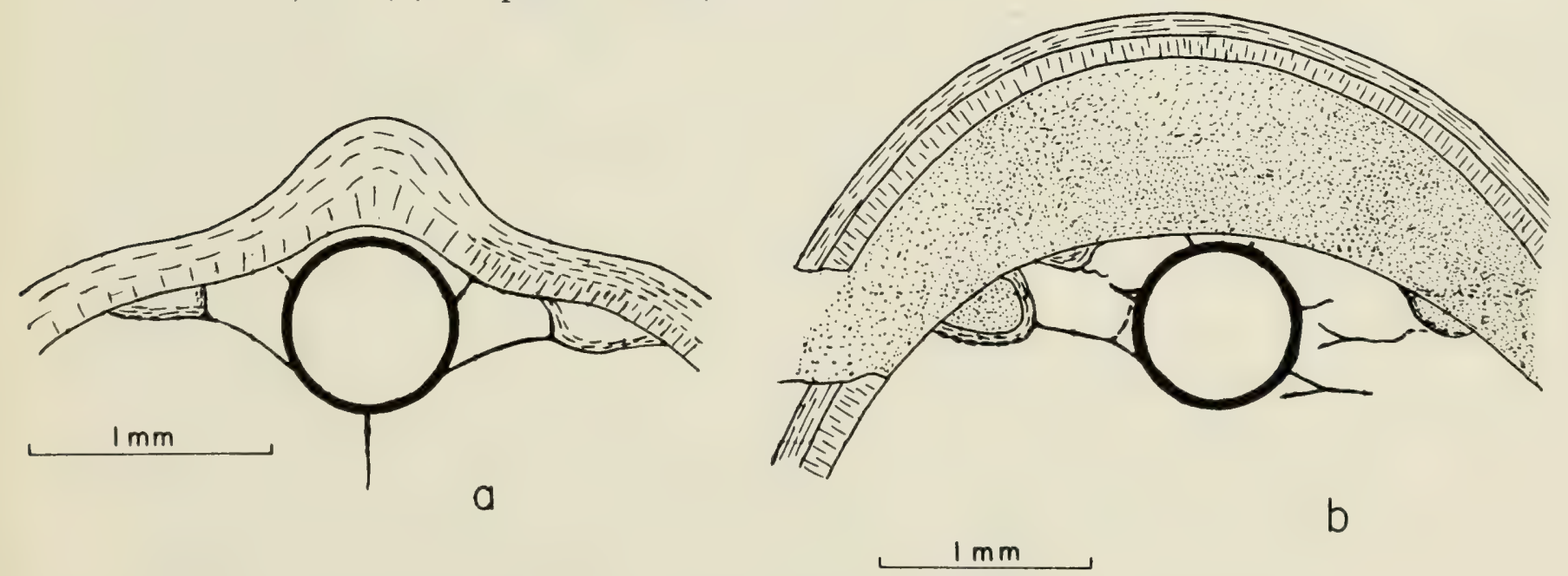

Figure 13. Attachment of the siphuncular tube in proximity of the septum by "horny" membranes; a, Grammoceras doerntense (Denkmann) at 16 $\mathrm{mm}$ diameter, test largely recrystallized; $b$, Phylloceras $\mathrm{cf}$. $P$. heterophyllum (Sowerby) at $30 \mathrm{~mm}$ diameter, test well preserved, but ventral wall exfoliated. 
between the septal necks is in contact with the ventral shell wall, directly or with the aid of secondary wall structures such as keel floors (Figs. 2-6, 12). The tube is probably always attached; otherwise the elastic tube would be suspended between the necks when under pressure. The usual attachment is by thick, short "horny" lamellae leading in pairs from the lower sides of the tube to the ventral wall (Fig. 6). The lamellae are attached to the surface of the tube, and are generally not direct extensions of the tube membranes as implied by Grandjean's figure (refigured in Hölder, 1952, p. $32 ; 1954)$. In proximity to the septa, very thin organic membranes or threads (indistinguishable in section or peel) are sometimes laterally, and even dorsally attached to the siphuncular tube which they connect with the septum (Fig. 13). With ribbed, spinose or keeled venters, complete attachment of the siphuncle is achieved by flattening of the ribs or by secretion of secondary test ("conellae matrix") including floors of keel and spines (Hölder, 1952).

Trueman's (1920) observation that the siphuncle is usually absent in the last chambers up to one whorl of young and adult Ammonitina shells also holds in the few specimens here examined. The whole siphuncle can be observed on exceptionally well preserved material, as R. A. Reyment, H. Hölder and J. Wiedman, have informed me. The destruction of the "horny" tube before and during fossilization quite obviously proceeded

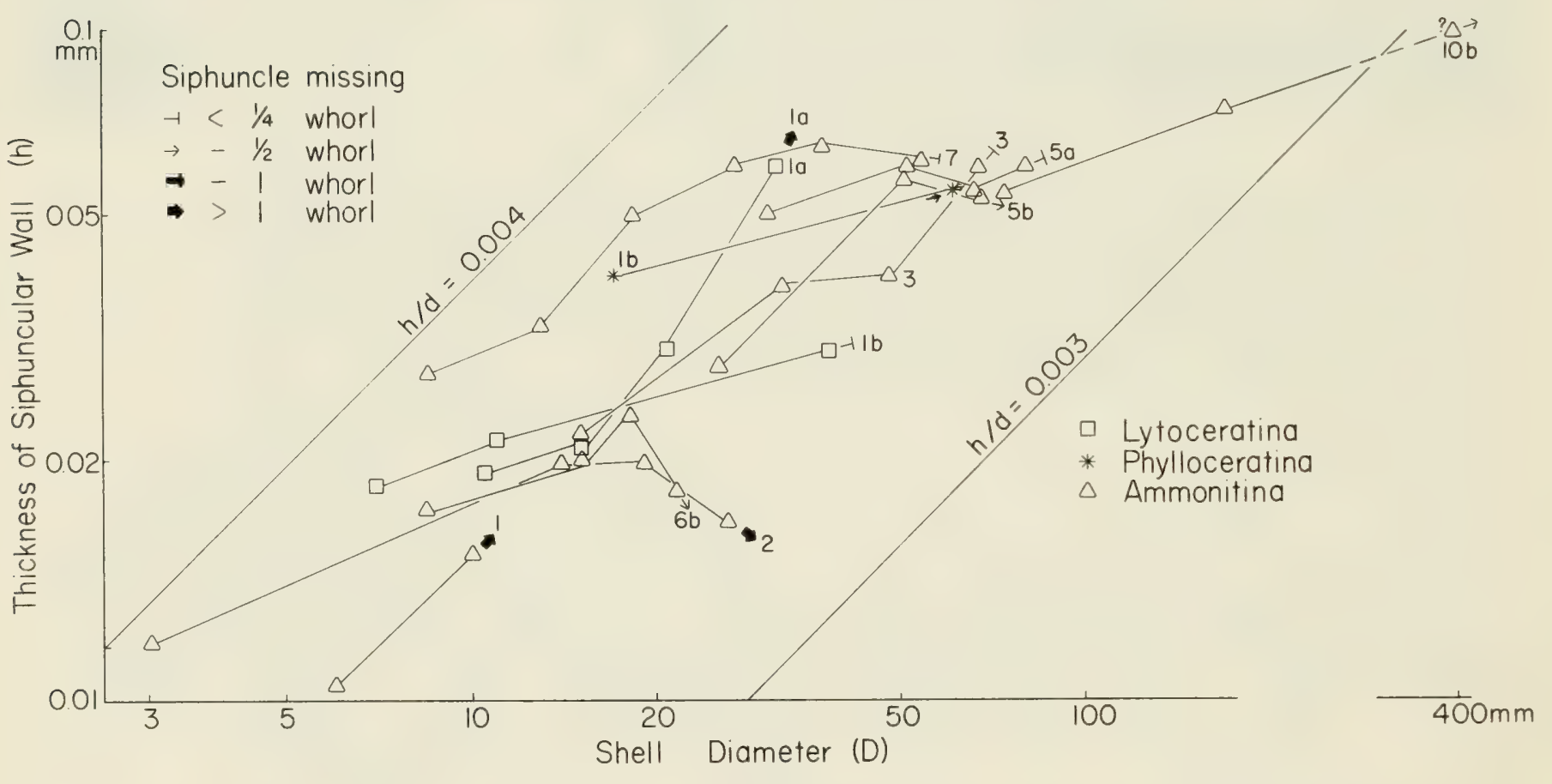

Figure 14. Ontogeny of the wall thickness of the siphuncular tube; completion indicated; double-logarithmic plot against diameter. Phylloceratina $(*)$ : 1 a, Phylloceras; Lytoceratina $(\square): 1 a, b$ Lytoceras; and Ammonitina $(\triangle):$ 1, Asteroceras, 2, Dactylioceras, 3, Grammoceras, 5a-b, Sonninia, 6 b, Stephanoceras, 7, Chondroceras, 10b, Placenticeras. For species see "Material" (B).

Allometry for wall thickness is negative, at least in the one to two last whorls (where preserved); absolute decrease is observed in mature Dactylioceras, Stephanoceras, and to a lesser degree in Sonninia and Chondroceras. 
from its open adoral end after the corpse had decayed or was removed from the shell with a part of the attached siphuncular strand; the remaining siphuncular strand would have plugged the siphuncular tube in the inner whorls. Nevertheless, my material gives some support for the suggestion by Mutvei (1967, p. 163) that the end of the siphuncular tube was relatively weak, due to slow development of the wall membranes; allometry for wall thickness of the mature tube (last one to two whorls) is quite consistently negative, and in the Ammonitina, wall thickness may even decrease absolutely before the tube is lost through early decomposition and fossilization, as shown in the diagram (Fig. 14). Early destruction of the siphuncular tube, which is expected to depend on the wall thickness, would also have an important implication for necroplanctonic transport of the shells, independent of shell features discussed by Reyment (1958).

The strength of the siphuncular tube against explosion, i.e. the maximal hydrostatic pressure under which the animal could survive, can be estimated from the data for wall thickness and radius of the tube, assuming that the tensile strength resembled that of Nautilus and that no marked shrinkage occurred during fossilization. Denton and Gilpin-Brown (1966, p. 754) have calculated the strength of two Nautilus tubes, which they believed to be the weakest structural part of the entire shell, to be respectively 35 and $37 \mathrm{~kg} / \mathrm{cm}^{2}$ (originally stated as 3.5 and 3.7 , regarded as lapsi calami). These measurements which, however, were based on tensile stress of exfoliated and probably altered tubes, correspond respectively to depths of 340 and $360 \mathrm{~m}$. Collins and Minton (1967) subjected the tube of a fresh Nautilus shell (in situ) to water pressure equalling a $480 \mathrm{~m}$ column, without breakage of the tube.

According to the calculations of Denton and Gilpin-Brown (1966) the wall thickness $h$ of Nautilus is approximately $12 \%$ of the tube radius $r$ at different shell diameters; the hydrostatic pressure limit $p$ is simply the ratio $h / r$ multiplied by the tensile strength $k$ of the material: $\mathrm{p}=\mathrm{k} \frac{h}{r}$. The relative strength index $h / r \times 100$ has been calculated and plotted for several ammonoids (Fig. 15) and gives useful relative estimates of siphuncular strength. The lowest and therefore critical value usually lies toward the end of the siphuncle; the greater relative wall thickness of the siphuncular tube of inner whorls perhaps developed at a later stage. Significantly, a strength index approximating or surpassing that of Nautilus is present only in the Lytoceratina and Phylloceratina $(h / r \times 100 \approx 10$ to 19$)$, while it is markedly lower in all examined Ammonitina with values for the mature siphuncular tube of only 3 to 6.5 , and the missing ends of the siphuncular tubes are inferred to have been weaker still.

There is a consistent negative allometry for the diameter of the siphuncular tube (2r) in the examined Ammonoidea and Recent Nautilus (Fig. 16). The tube diameter of most Ammonitina resembles that of Nautilus, with exception of Taramelliceras (larger) and Asteroceras and Dactylioceras (smaller). Phylloceratina and Lytoceras have much thinner tube diameters while the tetragonitid Pseudophyllites again resembles Nautilus. Since the rate of osmotic exchange of fluid between haemocoel and 


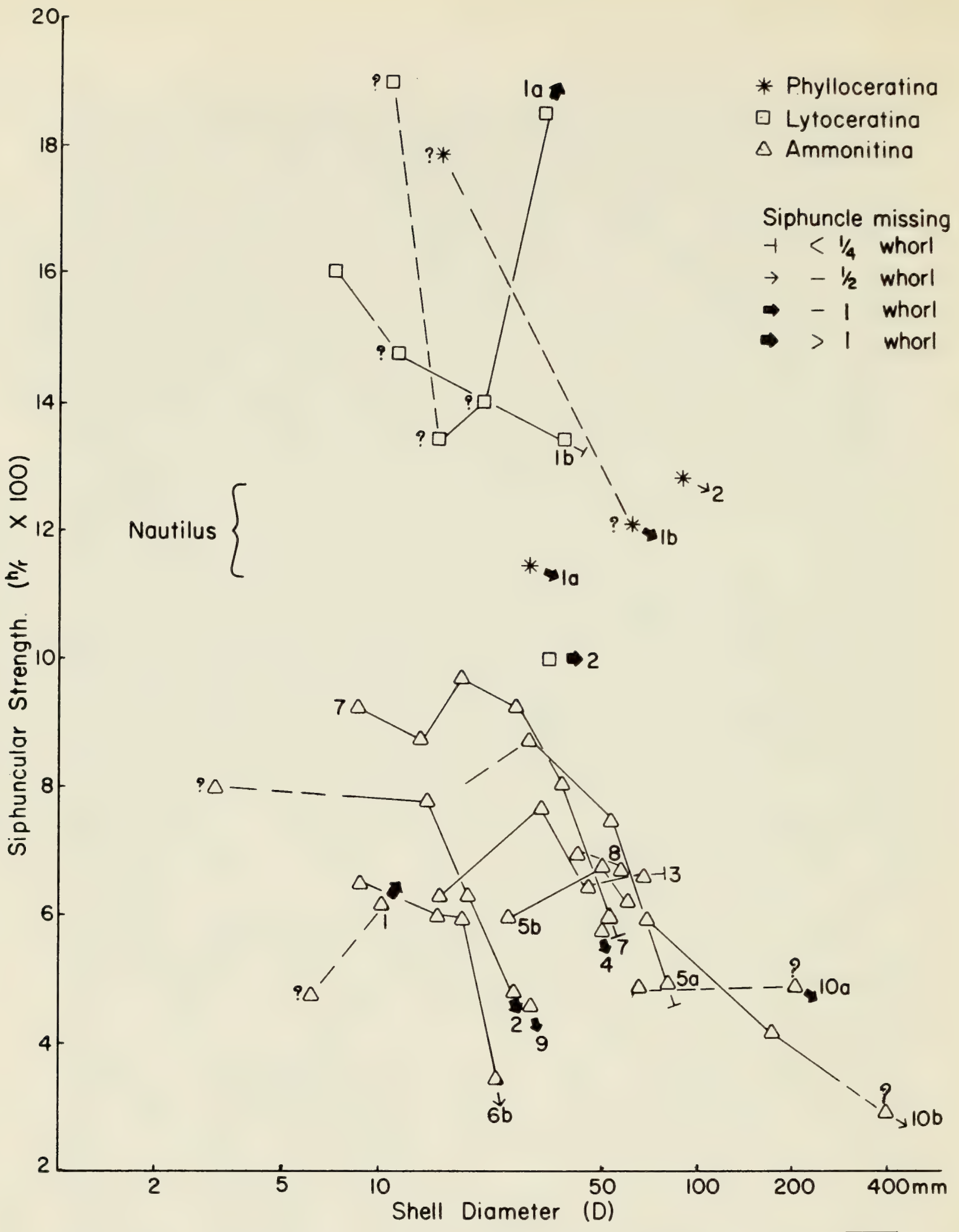

Figure 15. Ontogeny of the strength index of the siphuncular tube (siphuncular wall thickness/siphuncle radius (h/r) X 100); semi-logarithmic plot against diameter.

Phylloceratina (*): 1a-b, Phylloceras, 2, Calliphylloceras; Lytoceratina $(\square)$ : 1a-b, Lytoceras, 2, Pseudophyllites; and Ammonitina $(\triangle):$ 1, Asteroceras, 2, Dactylioceras, 3, Grammoceras, 4, Erycitoides, 5a-b, Sonninia, 6b, Stephanoceras, 7, Chondroceras, 8, Perisphinctes, and 10, Placenticeras. For species see "Material" (B). Index value ( $\sim 12)$ for present-day Nautilus from Denton and Gilpin-Brown (1966).

The strength of the siphuncular tube against explosion is consistently lower in Ammonitina than in Phylloceratina, Lytocerataceae and Nautilus; tube strength decreases in the last one to two phragmocone whorls of Ammonitina (siphuncle incomplete). 


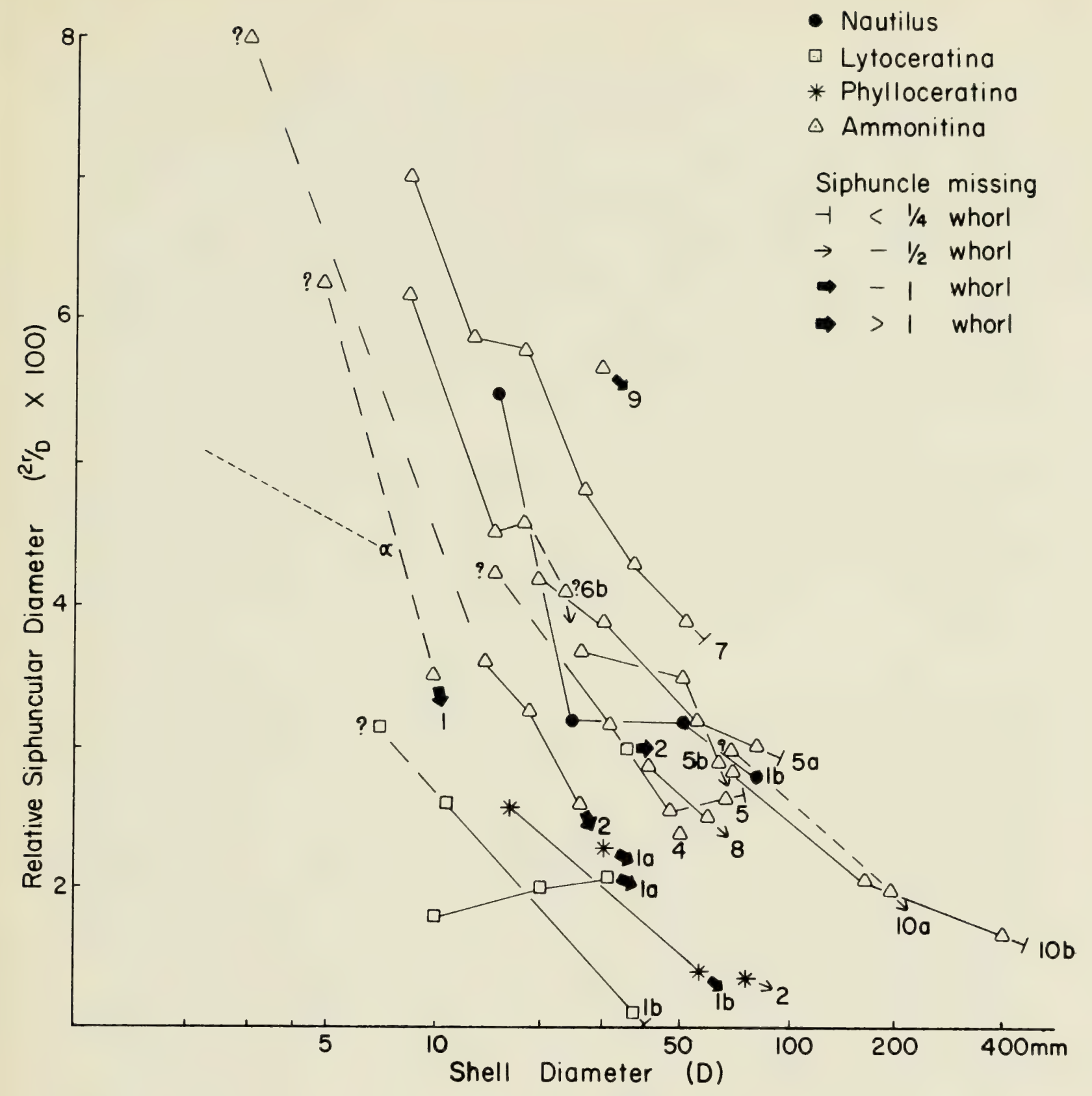

Figure 16. Ontogeny of the relative siphuncular tube diameter $\left(2 \mathrm{r} /{ }_{\mathrm{D}} \times 100\right)$; semi-logarithmic plot against diameter; completion indicated. Present-day Nautilus; Lytoceratina ( $\square$ ): 1a-b, Lytoceras, 2, Pseudophyllites; Phylloceratina (*): 1a-b, Phylloceras, 2, Calliphylloceras; and Ammonitina $(\triangle)$ : 1, Asteroceras, 2, Dactylioceras, 3, Grammoceras, 4, Erycitoides, 5a-b, Sonninia, 6b, Stephanoceras, 7, Chondroceras, 8, Perisphinctes, 9, Taramelliceras, 10a- $b$, Placenticeras, $\alpha$, Dactylioceras after Trueman, 1941; for species see "Material" (B).

Allometry of tube diameter is negative; the tube of Ammonitina tends to be similar to that of Nautilus and larger than those of Lytoceras and Phylloceratidae.

camerae is probably regulated by the siphuncular epithelium inside the tube (Denton and Gilpin-Brown, 1966), the siphuncular diameter could be expected to influence the rate of phragmocone growth so that neutral buoyancy is maintained. If this assumption is correct, siphuncular tube diameter (and circumference) should grow in relation to the area of the whorl section (Fig. 17), i.e. increase with the square of shell dimensions. Negative allometry of tube relative to shell diameter demonstrates, how- 


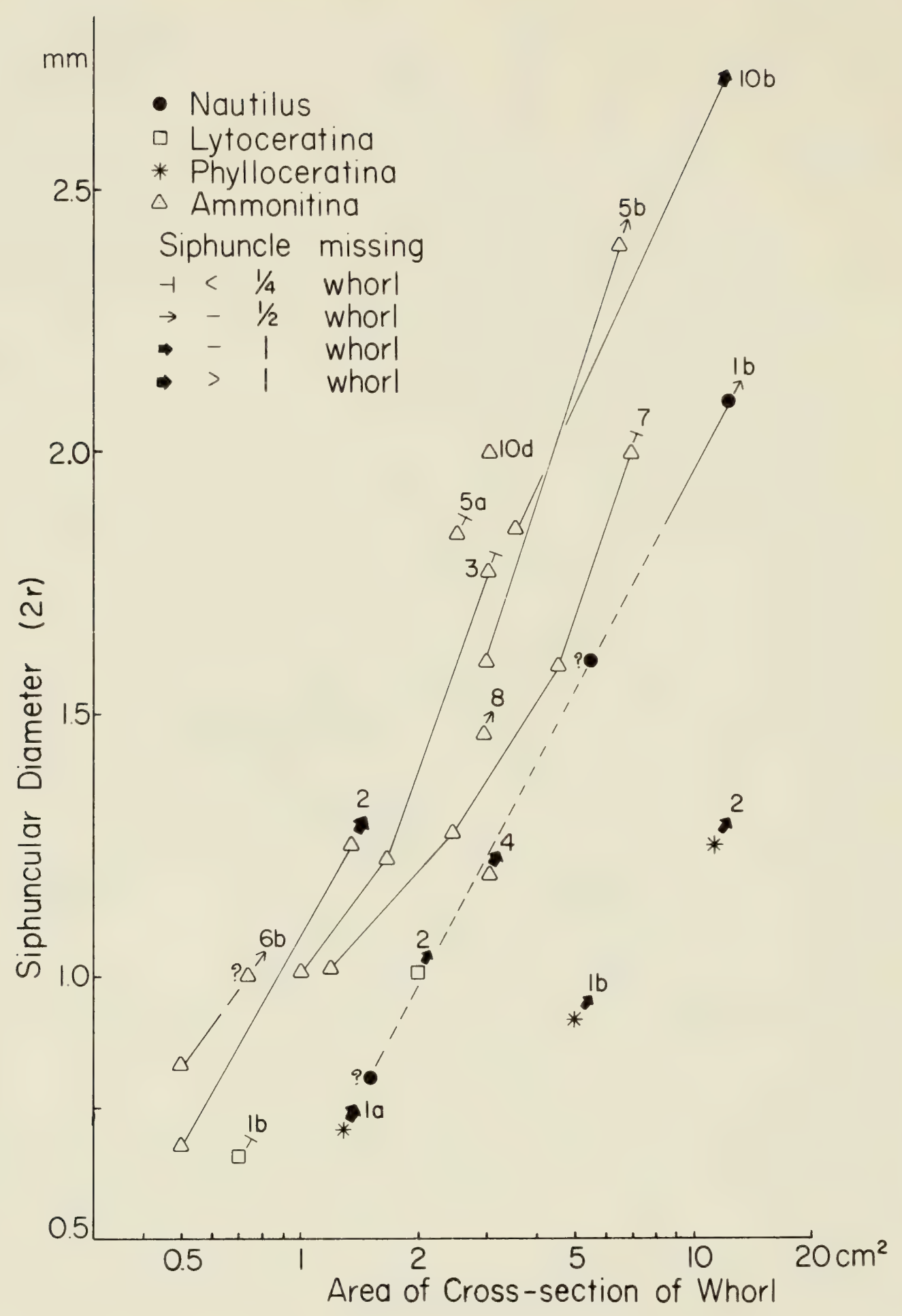

Figure 17. "Efficiency" of the siphuncular tube; relation between tube diameter (2r) and the area of cross-section of the whorl during ontogeny; semi-logarithmic plot; completion indicated.

Present-day Nautilus; Lytoceratina ( $\square$ ) : 1b, Lytoceras, 2, Pseudophyllites; Phylloceratina (*): 1a-b, Phylloceras, 2, Calliphylloceras; and Ammonitina $(\triangle): 2$, Dactylioceras, 3, Grammoceras, 4, Erycitoides, 5a-b, Sonninia, 6b, Stephanoceras, 7, Chondroceras, 8, Perisphinctes, and 10b-d, Placenticeras. For species see "Material" (B).

Siphuncular tube diameter (and tube surface) grows at a smaller rate than cross-section area. Tube diameter is therefore not so much related to the growth rate of the phragmocone as limited by tube strengths $(h / r)$. 
ever, that the osmotic rate does not limit the growth rate of the shell. Shell growth was inferred to be approximately constant (measured in the number of chambers added) in Nautilus (op. cit.). Growth of the siphuncular tube diameter appears to be restricted by the slow growth in thickness of its wall limiting the strength against explosion. This is supported by negative correlation between tube strength and absolute tube diameter, particularly in larger phragmocones. It appears plausible that the rate of buoyancy control is dependent on the diameter of the siphuncular tube for circadian and other short-period adjustments during feeding and resting periods, and that the diameter of the tube thus may reflect some ecological aspects of the animal.

The consistently marginal position of the siphuncle in the Ammonoidea, ventral except in the clymeniids, has never been satisfactorily explained from a functional aspect. The ventral position seems unsuited for the easy extraction of chamber fluid while the chambers are in the uppermost position, as supposed by Mutvei (1967) (see Chapter H).

\section{G. Growth Rate and Life Span}

Several independent sets of data suggest that Mesozoic ammonoids grew more slowly than most living cephalopods which reach full size in one or two years (for Nautilus cf. Denton and Gilpin-Brown, 1966; Eichler and Ristedt, 1966), and that the adult lifespan (unknown for Nautilus; A. Bidder, in litt.) was an additional several years. Four to six cycles, probably reflecting seasonal shell growth, are indicated by (1) whorl section and coiling (Trueman, 1941, Fig. 5; Raup, 1967, Text-fig. 10; Raup and Chamberlain, 1967, Text-fig. 2), (2) spacing of the septa (Oechsle, 1958, Abb. 7; Rieber, 1963, Abb. 9, 10), (3) size groups due to mass mortality (Swinnerton and Trueman, 1918), and (4) carbon isotope data on septa (Stahl and Jordan, 1969). The occurrence of several annual breeding and/or migratory seasons (discussion of Swinnerton in Trueman, 1941) is doubtful because all living cephalopods, so far as is known, have only a single cycle of breeding and migration per year. Adjustment to the slowly revolving increments of the growing ammonite shell (Merkt, 1966, p. 47) exhibited by relatively large epizoic oysters, repeated attachment of Placunopsis possibly representing annual spatfalls (Meischner, 1968), and my present observation of overgrowth of such oysters by the cone of Sonninia zitteli (Gottsche) provide additional evidence for the slow growth of ammonoid shells.

The male shells (microconchs) and, to a lesser degree, most female shells (macroconchs) of Ammonitina have modified apertures and several approximated, thickened terminal septa; these shells are fully grown before reaching maturity. It is possible that some males reach maturity (and terminate growth) earlier than the females if size dimorphism is strong (Westermann, 1964, p. 40). Marked modification of the body chamber (see Chapter $\mathrm{H}$ ) and aperture with test thickening probably reflects a long adulthood with several breeding seasons. Longevity is also supported by the presence of large epizoic oysters on the body chamber of the living 
animal (Seilacher, 1960 p. 193). A few large female shells (e.g. Sonniniidae; Oechsle, 1958) seem to have "unlimited growth" (throughout their life span) as is evident by the large variance of their size distributions and the absence of apertural modifications or marked septal approximation.

\section{H. Growth of the Body Chamber, Orientation and Buoyancy Control}

The adult body chamber of Ammonitina is almost always modified with respect to the juvenile and immature body chamber, although less obviously in the fully coiled forms. Consideration and recording of the growth stage is therefore essential for calculations of volumes, etc. of shells if constant growth rates are assumed. Although Raup has informed me that the measurements for his rather involved calculations of shell volume, based on a modification of the Moseley Equation (Raup and Chamberlain, 1967), were all made on phragmocones only, the results appear less accurate than those of Trueman (1941, p. 342).

The few records of complete or nearly complete juvenile and immature shells (due to a thin test and probably also migration or necroplanctonic drifting of the adult into environments offering a better chance of preservation) are consistent in that the body chamber is longer (measured as degrees of the spiral) than in the adult (see Huf, 1968); Trueman's (1941, p. 367) statement that the angular length of the body chamber in Promicroceras is similar throughout growth, is based on insufficient data. The adult reduction amounts to approximately one-quarter whorl for the average forms with $3 / 4$ whorls length of the adult body chamber (see Chapter C 1). It appears therefore that the last approximated and thickened septa (Figs. 8, 9) are built at a decelerated rate when the aperture essentially ceased normal growth, and concurrently with the development of the diverse apertural modifications, such as test thickening, collars and lappets. Adult shape modifications include, besides the well known umbilical egression, the common negative allometry for area of cross-section (Fig. 1; see Trueman, 1941, p. 348, fig. 7) which results from a decrease of the expansion rate, e.g., lateral "contraction" in depressed whorls.

One or both negative allometries (angular length and area of crosssection) result in the volume decrease of the adult body chamber relative to the phragmocone, suggesting that the adult animal would have become more buoyant. However, any buoyancy gain may have been cancelled out by the development of apertural modifications (thickening of the test, lappets, etc.).

The findings contradict the conclusion of Raup and Chamberlain (1967, p. 572), based on calculations of model shells with constant growth rates, that the angular length of the body chamber must increase ontogenetically in order to maintain neutral buoyancy. This would mean that the logarithmic spiral does not remain self-similar (exclusion of the nepionic stage of about $1 \mathrm{~mm}$ diameter would not alter significantly the overall weight and volume of the mature shell). Furthermore, an ontogenetic increase (not decrease, as stated in accordance with Trueman's data) of relative shell thickness would "avoid the necessity of increasing the length of the body chamber" (loc. cit.). 
The available estimates for life orientation of the coiled ammonoids (Trueman, 1941, p. 369; for shell models see Raup and Chamberlain, 1967) suffer from the omission of the adult modifications of the shell (in seawater, the test has a weight 20 to 30 times that of the soft parts), and necessarily, of the cameral fluid which is unknown as to quantity and distribution (see Bidder, 1962; Denton and Gilpin-Brown, 1966). In the adult shells, body chamber length (which is related to shell thickness and the expansion rate) varies from about $1 / 2$ whorl to $1 \frac{1 / 2}{2}$ whorls, with both the median and mean at approximately $3 / 4$ whorls (Trueman, 1941, table on p. 360). The life position of the last septum would therefore have varied greatly from horizontal to vertical with the siphuncle at the top, resembling the reproductions by Mutvei (1967, Text-fig. 1) for Promicroceras and by Trueman (1941, fig. 14b) for Stephanoceras (Normannites) of (although its large lappets would turn the aperture more downward so that the body chamber would have just reached over the top). The average immature body chamber of one whorl, however, would have reached well beyond the top with the last septum in an inclined to horizontal attitude (see Trueman, 1941, fig. 14a).

Mutvei (1967) has suggested that buoyancy control in the ammonoids involved the transport of the cameral fluid along the septal surfaces as in present day Nautilus. Swimming habit and buoyancy control of the living Nautilus and Sepia were recently investigated by Bidder (1962), and Denton and Gilpin-Brown (1961, 1963, 1966). In Nautilus, cameral fluid "decoupled" (not in direct contact) from the siphuncle is believed to be transported along both septal surfaces by means of (1) the porous prismatic and spherulitic-prismatic layers respectively, the latter being continuous onto the siphuncular tube (but see Chapter E), and ( 2 ) by the thin hydrophilic conchiolin membranes covering these layers. The liquids are then transported through the permeable tube of the siphuncle (see Denton and Gilpin-Brown, 1966) by osmotic differentials which are controlled by the animal within the siphuncular epithelium. Since porous and permeable shell layers of septa and siphuncle are unknown in the ammonoids, Mutvei suggests that liquid transport along the conchiolin membranes is there increased by corrugation and fluting of the septa (see Chapter E2).

The extreme ventral rather than dorsal position of the siphuncle seems functionally ill-suited for extraction of fluid from the uppermost chambers of the coiled phragmocone with "decoupled" liquid, as assumed in Mutvei's hypothesis. On the other hand, the ventral position would assure (1) at least partial immersion of the siphuncle with more efficient extraction of fluid from the lateral chambers and (2) the complete immersion of the siphuncle in the lowermost chambers until the chambers are emptied. It is therefore tentatively suggested that, at least in "average" adult animals with an upward position of the last chambers, circadian and similar shortterm buoyancy regulation is accomplished by the "osmotic pump" (Denton and Gilpin-Brown, op. cit.) in the lowermost chambers only. I realize, however, that Bidder's 1962 report on living Nautilus of liquids in similar positions has not been substantiated by Denton and Gilpin-Brown (1966, 
p. 738). The fluid in the lowermost chambers would also increase the stability of the animal by lowering of the centre of gravity.

While the last few chambers with slow growth of "average" adult ammonoids (with $3 / 4$ whorls body chamber) may be emptied, at least partially, by transport of the fluid along the septal surfaces as proposed by Mutvei (1967) (? and along wall surfaces, see Chapter E), this is obviously not always so, since the last chambers are in a lateral position in most immature ammonoids and in those adults with an exceptionally long or short body chamber (also most "heteromorphs"). As growth continues, the chambers are usually rotated into a progressively more downward position so that the siphuncle remains immersed as the fluid is completely drawn out if required (for Nautilus see Denton and Gilpin-Brown, 1966, p. 738).

While this paper was in press, W. B. Heptonstall ("Buoyancy control in Ammonoids," Lethaia $3: 317-328,1970$ ) reported his recalculations of buoyancies of ammonoid shells and estimations of the proportion of cameral fluid present in the living animals, based on the data of Trueman (1941). Since he has implicitly assumed the growth rates to be constant, he has neglected the body chamber and apertural modifications. Thus the slowly increasing weight of the epizoic oysters on the growing Buchiceras shell could have been compensated for by a decrease in allometric rate of wall thickness or volume of the body chamber (known to occur during maturation); modification of the growth spiral in compensation for asymmetric oyster attachment was described by Merkt (1966). The correction of Truman's formula for density of the ammonoid body (c. 3-12\%) appears insignificant considering Trueman's gross error in the estimation of body density, which in fact is very close to that of sea water (Heptonstall has used the lower density value in his calculations; however, I fail to understand why, in Table 2, calculated values of 1.0 indicate large amounts of cameral fluid). Trueman's estimate was derived from the buoyancy of a dried-out Nautilus shell and hence included compensation for the lost cameral fluid (although he was unaware of this). His relatively minor errors in the volume formula and constant for test density could have been compensated for by the weight of the aperture which he knowingly omitted and of the additional test thickness (partly lost during diagenesis). Any calculations assuming an error of only $5 \%$ must be based on detailed measurements including all these structures. The minimum amount of cameral fluid, however, can be estimated easily for the growing shell assuming it equals the volume increment of a single chamber, e.g. in an average shell with expansion rate $\mathrm{W}=2$ and 20 camerae per whorl, the increment would be about $10 \%$ (compared with about $17 \%$ in Nautilus pompilius). The complete exchange of fluid between camarae and haemocoel during rapid (circadian) vertical movement of the animal is indeed unlikely; there is no reason why the hyponome should not have effected such movement. Heptonstall's assumption that the ventro-marginal position of the siphuncle is to increase its length and therefore surface area seems to be incompatible with the frequently observed contact of the siphuncle with the shell wall apparently reducing the effectıve surface, with 
the dorso-marginal position in the clymeniids, and with the subcentral position in the nautilids in which the differential between ventral and dorsal arcs is larger than in the ammonoids because of the higher expansion rate and tighter coiling. I disagree entirely with his propositions regarding the genetics and evolution of ammonoids; I hope to discuss this at a later date.

\section{Bathymetry and Siphuncular Strength}

Few significant attempts have been made in the last decades to determine the habitats of Mesozoic coiled ammonoids. Any arguments have to take into account the probability of seasonal migration, sex segregation and similar autecological factors known to occur in the present-day cephalopods (see Westermann, 1969b, p. 18), as well as the diverse attributes of the empty shells causing them to sink or float for varying distances, such as shell shape and structure (Reyment, 1958) and siphuncular wall thickness (see Chapter F). R. A. Reyment has informed me that he and E. Stähl are presently making models of a wide variety of shell shapes for further experiments. Necroplanctonic drift would also appear to depend on the depth of the animal at the instant of death, since under pressure the chambers would fill up with water through the unbroken siphuncular tube in only a few hours (Collins and Minton, 1967); the well-known extensive drifting of present-day Nautilus shells would therefore appear to be due to death in surface waters.

Among ammonoids, the phylloceratids and coiled lytoceratids have long been correctly supposed to inhabit the relatively deepest waters (see Spath, 1919). Scott (1940) attempted to determine the bathymetry of the habitats for the Ammonitina and "heteromorphs" of the Albian (Cretaceous) beds of the Texas area. However, his conclusions of a nectobenthonic habitat, including frequent crawling on the bottom, for all the great variety of forms encountered, and in particular his generalizations relating shell form with bathymetry of habitat, cannot be accepted. More recently, distinct ammonite biofacies have been reported, particularly from the Middle Jurassic of Germany (Westermann, 1954, p. 44) and England (Torrens, 1967, p. 84); and from the Upper Jurassic of Europe (Ziegler, 1967 and papers listed therein). Ziegler, again, drew conclusions with respect to the bathymetry of habitats, but he $(1967$, p. 460$)$ also refuted the existence of any known correlation of general validity between shell form and bathymetry of habitat.

Some correlations between shell form and habitat may be conjectured, although most of them are taxonomically restricted to certain superfamilies and perhaps suborders: highly ornate planulate and discoidal ammonoids with "average" ammonitic septal sutures, as well as many with (ceratitic? and) pseudoceratitic sutures appear to have predominated in shallow water; Jurassic cadicone ammonites with complex sutures seemingly preferred somewhat greater depths (and/or less agitated water); most Phylloceratina and coiled Lytoceratina, with circular to perfectly ovate whorl section and complex sutures, usually lived in deep water. It 
is possible that the common mature weakening of the siphuncular wall in the Ammonitina reflects migration of the maturing animal to shallow water (for breeding). The tentative ecological conclusions of bathymetry of habitat of the studied genera, relative to living Nautilus, are indicated in the last column of Table 1 .

A promising new bathymetric indicator appears to be the siphuncular tube; the thickness data of the septum and of the shell wall seem to be somewhat less useful, probably owing to the complex mechanical interrelationship and multiple function of these structures. Significantly, both the Phylloceratina and Lytoceratina are distinguished from all examined Ammonitina in the much thicker wall and the smaller diameters of the siphuncular tube reflecting greater strength against explosion due to the great hydrostatic pressure exerted by the haemocoelic fluid extending from the body into the siphuncle, occurring when they are in deep water. While the estimated strength of the siphuncular tube of phylloceratids and coiled lytoceratids probably approximated that of living Nautilus (which can withstand at least a $450 \mathrm{~m}$ water column), the comparative values for mature and almost mature Ammonitina are only about one-half to one-quarter as high. 


\section{Literature Cited}

ARKELL, W. J.

1957 Sutures and septa in Jurassic ammonite systematics. Geol. Mag. XCIV: 235-248.

BIDDER, A. M.

1962 Use of the tentacles, swimming and buoyancy control in the Pearly Nautilus. Nature 196 (4853) : 451-454.

BIRKELUND, $T$.

1967 Submicroscopic shell structure in early growth-stage of Maastrichtian ammonites (Saghalinites and Scaphites). Dansk Geol. Forening, Medd. 17 (1): 95-101, pl. 1-4.

BIRKELUND, T., AND H. J. HANSEN

1968 Early shell growth and structure of septa and the siphuncular tube in some Maastrichtian ammonites. Dansk Geol. Forening, Medd. 18 (1) : 71-78, pl. 1-4.

BUCKMAN, S. S.

1892 A monograph of the Inferior Oolite ammonites of the British Islands, part. VII. Palaeontograph. Soc., 1892, p. 313-344, pl. LVII-LXXVI.

CALLOMON, J. H.

1963 Sexual dimorphism in Jurassic ammonites. Leicester Lit. Phil. Soc., Trans. 57: 21-56.

1969 Dimorphism in Jurassic ammonites, some reflections. In G. E. G. Westermann (Ed.); Sexual dimorphism in fossil Metazoa and taxonomic implications. Int. Union Geol. Sci., Ser. A, 1: 111-125.

CHAMBERLAIN, J. A., JR.

1969 Technique of scale modelling of cephalopod shells. Palaeontology $12: 48-55$.

COBBAN, W. A

1969 The late Cretaceous ammonites Scaphites leei Reeside and Scaphites hippocrepis (Dekay) in the Western Interior of the United States. Geol. Surv., Prof. Pap. 619: 1-29, pl. 1-5.

COLLINS, D. H. AND P. MINTON

1967 Siphuncular tube of Nautilus. Nature 216 (5118): 916-917.

COPE, J. L.W.

1967 The palaeontology and stratigraphy of the lower part of the upper Kimmeridge Clay of Dorset. Brit. Mus. (Nat. Hist.), Bull. Geol. 15: 1-79, pl. 1-33.

DENTON, E. J. AND J. B. GILPIN-BROWN

1961 The distribution of gas and liquid within the cuttlebone. Mar. Biol. Ass. U.K., J. 41 : 365-381.

1963 On the buoyancy of the Pearly Nautilus. J. Physiol. 168: 44-45.

1966 On the buoyancy of the Pearly Nautilus. Mar. Biol. Ass. U.K., J. 46: 723-759.

DONOVAN, D. T.

1964 Cephalopod phylogeny and classification. Biol. Rev. 39: 259-287. EICHLER, R. AND H. RISTEDT

1966 Untersuchungen zur Frühontogenie von Nautilus pompilius (Linné). Palaont. Z. 40: 173-191, pl. 16-17. 
ERBEN, H. K., G. FLAJS AND A. SIEHL

1969 Die Frühontogenetische Entwicklung der Schalenstruktur ectocochliater Cephalopoden. Palaeontographica, Abt. A, 132: 1-54, pl. 1-15.

HOLDER, $\mathrm{H}$.

1952 Über Gehäusebau, insbesondere Hohlkiel jurassischer Ammoniten. Palaeontographica, Abt. A, 102: 18-48, pl. 3-7.

1954 Über die Siphoanheftung bei Ammoniten. Neues Jahrb. Geol. Paläont., Monatsh. 1954: 372-379.

HOWARTH, M. K. AND D. T. DONOVAN

1964 Ammonites of the Liassic family Juraphyllitidae in Britain. Palaeontology 7: 286-305.

HUF, W.

1968 Über Sonninien und Dorsetensien aus dem Bajocium von Nordwestdeutschland. Beih. Geol. Jahrb., Heft 64: 1-126, pl. 1-51.

JORDAN, R.

1968 Zur Anatomie mesozoischer Ammoniten nach den Strukturelementen der Gehäuse-Innenwand. Beih. Geol. Jahrb., Heft 77: 1-64, pl. 1-10.

KÄLIN, I.

1967 Ein Wunderwerk der Statik: Der Schulp des Tintenfisches. Mikrokosmos, 8: 230-238.

KUMMEL, B. AND R. M. LLOYD

1955 Experiments on relative streamlining of coiled cephalopod shells. J. Paleont. 29: 159-170.

LEHMANN, U.

1966 Dimorphismus bei Ammoniten der Ahrensburger Lias-Geschiebe. Paläont. Z. 40: 26-55, pl. 3-4.

1969 Dimorphismus und Apophysen-Ausbildung bei Grammoceras doerntense (Denkmann) (Ammonoidea; Oberes Toarcium). Paläont. Z. 43: 169-176, pl. 20.

MAKOWSKI, H.

1963 Problem of sexual dimorphism in ammonites. Palaeont. Polonica, 12, 1-92.

MEISCHNER, D.

1968 Perniciöse Epökie von Placunopsis auf Ceratites. Lethaia 1: 156174.

MERKT, J.

1966 Uber Austern und Serpeln als Epöken auf Ammonitengehäusen. Neues Jahrb. Geol. Paläont., Abh. 125: 467-479, pl. 42.

MUTVEI, $\mathrm{H}$.

1964(a) On the secondary internal calcareous lining of the wall of the siphonal tube in certain fossil "nautiloid" cephalopods. Arkiv Zool., 16, No. 21: 375-424, pl. 1-29.

1964(b) On the shells of Nautilus and Spirula with notes on the shell secretion in non-cephalopod mollusks. Arkiv Zool., 16, No. 14: 221-278, pl. 1-22.

1967 On the microscopic shell structure in some Jurassic ammonoids. Neues Jahrb. Geol. Paläont., Abh. 129: 157-166. 
NEWELL, N. D.

1949 Phyletic size increase, an important trend illustrated by fossil invertebrates. Evolution 3: 103-124.

OECHSLE, E.

1958 Stratigraphie und Ammonitenfauna der Sonninien-Schichten des Filsgebietes unter besonderer Berücksichtigung der Sowerbyi-Zone (Mittlerer Dogger, Württemberg). Palaeontographica, Abt. A, 111: 47-129, pl. 10-20.

PALFRAMAN, D. F. B.

1966 Variation and ontogeny of some Oxfordian ammonites: Taramelliceras richei (De Loriol) and Creniceras renggeri (Oppel), from Woodham, Buckinghamshire. Palaeontology 9: 290-311, pl. 4852.

1967 Variation and ontogeny of some Oxford Clay ammonites: Distichoceras bicostatum (Stahl) and Horioceras baugieri (D'Orbigny), from England. Palaeontology 10: 60-94, pl. 9-13.

PFAFF, E.

1911 Über Form und Bau der Ammonitensepten und ihre Beziehungen zur Suturlinie. 4. Jahresber. Niedersächs. geol. Vereins Hannover, p. 207-223, pl. XI.

RAUP, D. M.

1966 Geometric analysis of shell coiling: general problems. J. Paleont. 40: 1178-1190.

1967 Geometric analysis of shell coiling: coiling in ammonoids. J. Paleont. 41: 43-65.

RAUP, D. M. AND J. A. CHAMBERLAIN, JR.

1967 Equations for volume and centre of gravity in ammonoid shells. J. Paleont. 41 : 566-574.

REYMENT, R. A.

1958 Some factors in the distribution of fossil cephalopods. Stockholm Contr. Geol. 1 : 97-184, pl. I-VII.

RIEBER, H.

1963 Ammoniten und Stratigraphie des Braunjura $\beta$ der Schwäbischen Alb. Palaeontographica, Abt. A, 122: 1-89, pl. 1-8.

SCHINDEWOLF, O. H.

1961 Zur Stammesgeschichte der Ammoniten. Lief. 1. Akad. Wiss. Lit., Abh. Math.-naturwiss. Kl., Jahrg. 1960, No. 10: 635(1)-743(109), pl. 1-2.

SCOTT, G.

1940 Paleoecological factors controlling the distribution and mode of life of Cretaceous ammonoids in the Texas area. J. Paleont. 14: 299-323.

SEILACHER, A.

1960 Epizoans as a key to ammonoid ecology. J. Paleont. 34: 189-193. SPATH, L. F.

1919 Notes on ammonites. Geol. Mag. LVI: 27-35, 65-74, 115-122, 170 $177,220-225$.

STAHL, W. AND R. JORDAN

1969 General considerations on isotopic paleotemperature determinations and analyses on Jurassic ammonites. Earth Planet. Sci. Lett. 6: 173-178. 
SWINNERTON, H. H. AND A. E. TRUEMAN

1918 The morphology and development of the ammonite septum. Geol.

Soc. London, Quart. J. 73: 26-57, pl. 2-4.

TEICHERT, C.

1967 Major features of cephalopod evolution. In C. Teichert and E. L. Yochelson (Eds.): Essays in paleontology and stratigraphy. R. C. Moore commemorative volume. Dept. Geol. Univ. Kansas, Spec. Publ. 2: 162-210.

TORRENS, H. S.

1967 The Great Oolite limestone of the Midlands. Leicester Lit. Phil. Soc., Trans. LXI: 65-90.

TRUEMAN, A. E.

1920 The ammonoid siphuncle. Geol. Mag. 1920: 26-32.

1941 The ammonite body-chamber, with special reference to the buoyancy and mode of life of the living ammonite. Geol. Soc. London, Quart. J. 96: 339-383.

WESTERMANN, G. E. G.

1954 Monographie der Otoitidae (Ammonoidea). Beih. Geol. Jahrb., Heft 15: 1-364, pl. 1-33.

1956 Phylogenie der Stephanocerataceae und Perisphinctaceae des Dogger. Neues Jahrb. Geol. Paläont., Abh. 103: 233-279.

1958 The significance of septa and sutures in Jurassic ammonite systematics. Geol. Mag. xcv: 441-455.

1964 Sexual-Dimorphismus bei Ammonoideen und seine Bedeutung für die Taxionomie der Otoitidae. Paleontographica, Abt. A, 124: 33-73.

1966 Covariation and taxonomy of the Jurassic ammonite Sonninia adicra (Waagen). Neues Jahrb. Geol. Päleont., Abh. 24: 389-412.

1969(a) The ammonite fauna of the Kialagvik Formation at Wide Bay, Alaska Peninsula. Part II. Sonninia sowerbyi Zone. Bull. Am. Paleont., 57, No. 255: 1-226, pl. 1-47.

1969(b) (ed.) Sexual dimorphism in fossil Metazoa and taxonomic implications. Int. Union Geol. Sci., Ser. A, 1: 1-251, pl. 1-14.

WIEDMANN, J.

1969 The heteromorphs and ammonoid extinction. Biol. Rev. 44: 563602.

ZACHAROV, YU. D.

1969 Problems of sexual dimorphism in fossil cephalopods, an important subject in modern systematics, p. 108-127. In M. N. Gramm and V. A. Krassilov: Problems of phylogeny and systematics. Acad. Sci. U.S.S.R., Far East Geol. Inst.; All-Union Palaeont. Soc., Vladivostok branch, p. 1-143. [in Russian]

ZIEGLER, B.

1967 Ammoniten-Ökologie am Beispiel des Oberjura. Geol. Rundschau 56: $439-464$. 




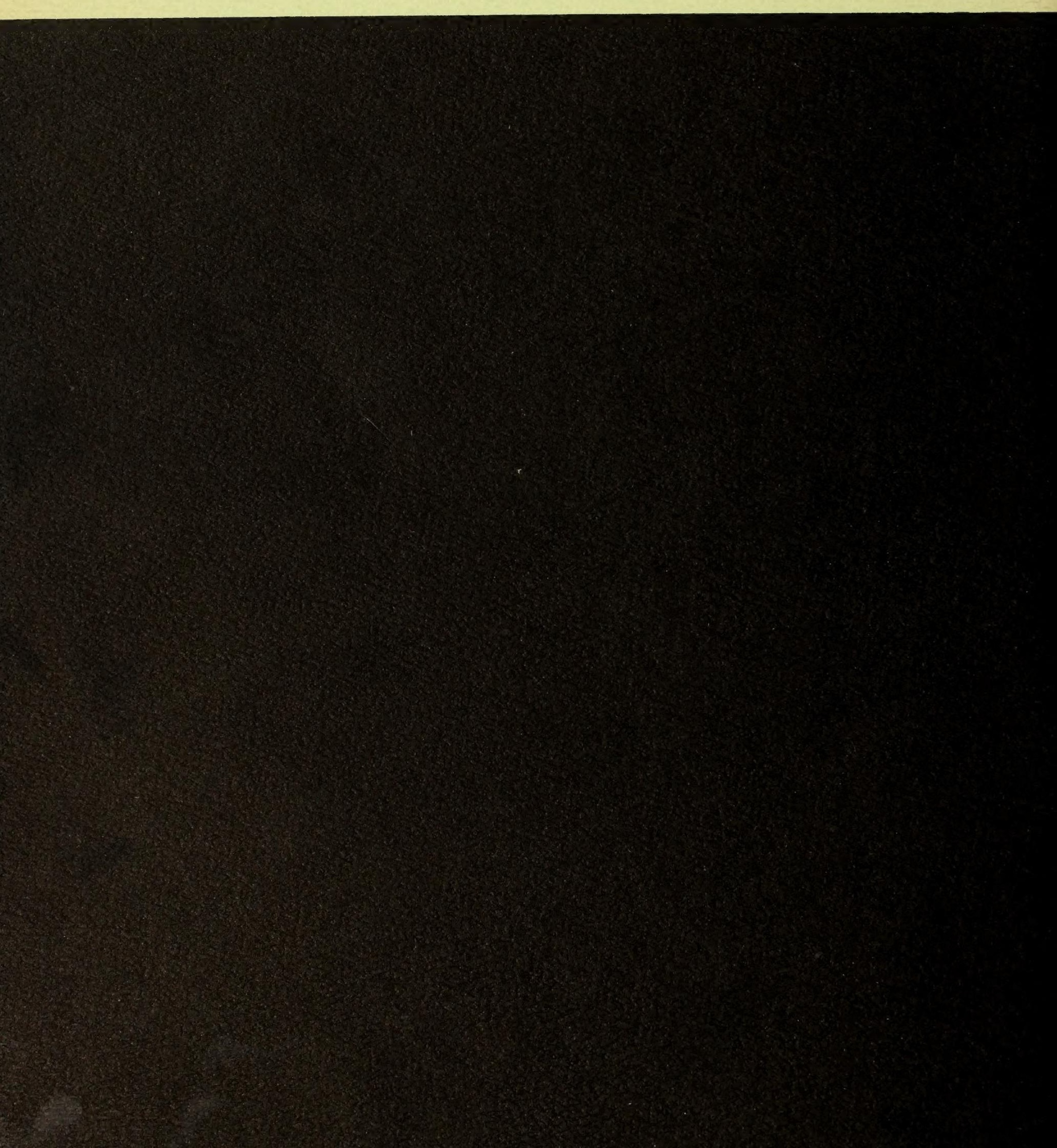

